WSRC-TR--92-72

DE92 018108

\title{
NRTSC
}

NUCLEAR REACTOR TECHNOLOGY

AND SCIENTIFIC COMPUTATIONS

Keywords:

PTERM

Heat Exchanger

Acceptance Criteria

IGSCC

Retention - Permanent

\section{SAVANNAH RIVER REACTOR PROCESS WATER HEAT EXCHANGER TUBE STRUCTURAL INTEGRITY MARGIN TASK NUMBER 92-005-1 (U)}

\section{By}

\author{
G. E. Mertz \\ D. M. Barnes \\ R. L. Sindelar
}

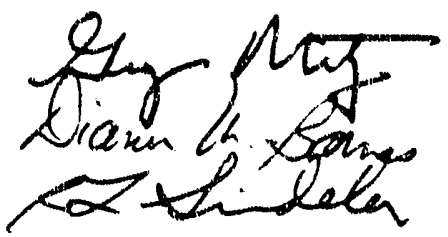

Issued: February 1992

$$
\text { G.C. Kon 2/27/92 }
$$

Derivative Classifier

SRL SAVANNAH RIVER LABORATORY, AIKEN, SC 29808

Westinghouse Savannah River Cumpany

Prepared for the U.S. Department of Energy under Coniract DE-AC09-76SR00001

Presently under Contract DE-AC09-88SR18035

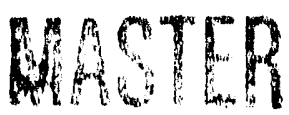


PROJECT: Heat Exchanger Tube Acceptance Criteria

DOCUMENT: WSRC-TR-92-72

TITLE: Savannah River Reactor Process Water Heat Exchanger Tube Structural Integrity Margin (U)

TASK: $\quad 92.005 .1$

APPROVALS
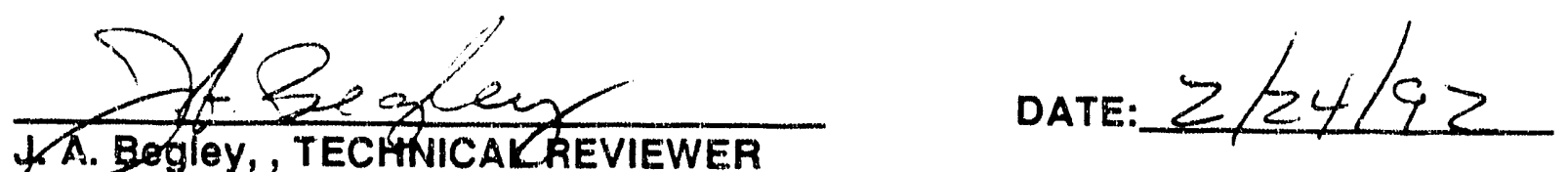
WESTINGHOUSE SCIENCE \& TECHNOLOGY CENTER

Na dur Gupta

N. K. Gupta, TECHINICAL REVIEWER MATERIALS TECHNOLOGY

N.G. Quadalla

N. G. Awadalla, MANAGER MATERIALS TECHNOLOGY

T. L. Capelettl, MANAGER MATERIALS TECHNOLOGY
DATE: $2 / 26 / 92$

DATE: $76,28,1992$

DATE: $21 / 28 / 92$ 


\section{Table of Contents}

1. Inroduction and Conclusions Page

1.1. Structural Design Capacity .........................................

1.2. Structural Requirements for Minimum Thickness..........................

1.3. Structural Requirements for Maximum Flaw Size ......................

1.4. Reference Leakage Size Flaw and Structural Margins ....................2

1.5. Inspection Acceptance Criteria..........................................

2. Component Description..................................................... 3

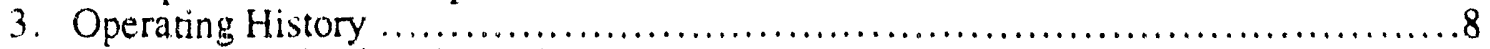

3.1. Mechanical Degradation ............................................ 8

3.2. Corrosion ........................................................ 8

4. Structural Requirements ..................................................... 10

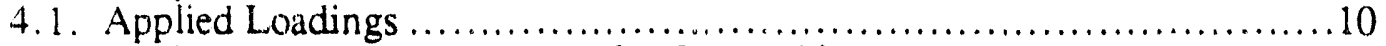

4.2. Minimum Wall Requirements for Gross Thinning ......................14

4.3. Minimum Wall Requirements for Localized Thinning....................18

4.4. Allowable Flaw Sizes..............................................20

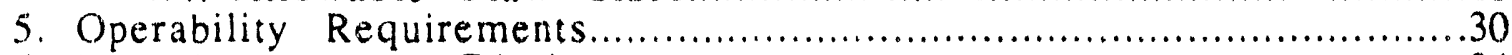

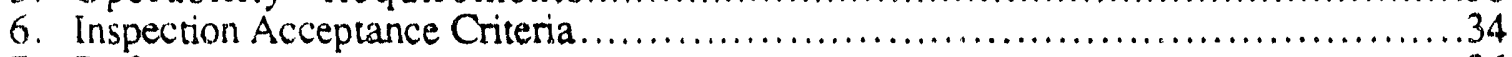

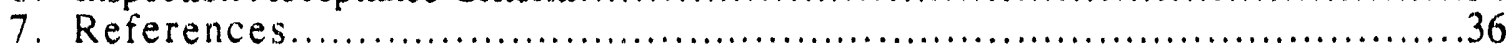




\section{List of Figures}

Process Water System Heat Exchanger.............................................

2 Tubing Restrain at Tube Sheet or Baffle................................................23

3 Allowable Depth and Length of Locally Thinned Areas ............................23

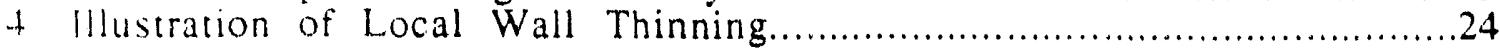

5 Allowitble Locally Thinned Areas for Normal Operating and Accident ...............25 Conditions

6 Allowable Locally Thinned Areas for Normal Operating Conditions on ..............26 the Cold End of the Heat Exchanger ( $\Delta \mathrm{P}=110$ psid)

7 Cross Section of Flawed Pipe ....................................................27

8 Allowable End of Life Flaw Size for Circumferential Flaws .......................28

9 Allowable End of Life Flaw Size for Axial Flaws.....................................29

10) Leak Rate for a Circumferential Heat Exchanger Tube Crack..........................32

11 Leak Rate for an Axial Heat Exchanger 'Tube Crack ..............................32

12 Leak Rate for a Heat Exchanger Tube Pit ........................................ 33

\section{List of Tables}

1 Heat Exchanger Operating and Design Conditions............................ 3

2 Heat Exchanger Materials of Construction ..................................5

3 Heat Exchanger Purchase Information...........................................5

4 Materials of Construction for the K. Reactor Heat Exchangers..........................6 In Service -.. 2/1/92

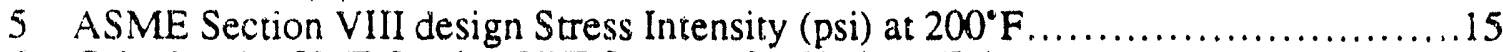

6 Calculated ASME Section VIII Stresses for Various Tube .............................17 Wall Thicknesses

7 Calculated ASME Section VIII Stresses for Various Pressures ......................18

8 Load Summary for Local Wall Thinning Analysis .................................... 19

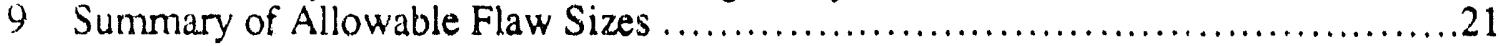

10 Structural Margins on length for Heat Exchanger Tubing............................ 31

11 a Heat Exchanger Tubing Allowable End-Of-Evaluation Period ......................35 Wall Thickness

$11 \mathrm{~b}$ Heat Exchanger Tubing Allowable End-Of-Evaluation Period Flaw.................35 Depth To Thickness Ratios for Circumferential Flaws

$11 \mathrm{c}$ Heat Exchanger Tubing Allowable End. Of-Evaluation Period Flaw .................35 Depth To Thickness Ratios for Axial Flaws 


\section{SUMMARY}

Twelve pocess water heat exchangers are designed to remove heat generated in the reactor tank. Each heat exchanger has approximately $9000,1 / 2$ " diameter $\times 0.049^{\prime \prime}$ thick tubes. Minimum structural tubing requirements and the leak rate through postulated tubing defects are developed in this report. A comparison of the structural requirements and the defect size calculated to produce leak rates of $0.5 \mathrm{lbs}$./day demonstrate adequate structural margins against gross tube rupture.

Commercial nuclear experience with pressurized water reactor (PWR) steam generator plugging criteria are used for guidance in performing this analysis. It is important to note that the SRS reactors are low energy systems with normal operating pressures of 203 psig at $130^{\circ} \mathrm{F}$ while the PWR is a high energy system with operating pressures near 2200 psig at $600^{\circ} \mathrm{F}$. Clearly the PWR steam generator has loadings which are more severe than the SRS heat exchangers.

The commercial basis for plugging PWR steam generator tubing is defined by Regulatory Guide 1.121 which is explicitly limited to PWRs. However, where applicable, this. guideline is applied in the current evaluation of the SRS heat exchanger tubing.

Consistent with the Regulatory Guide 1.121 criteria both wastage (wall thinning) and cracking are addressed. Structural limits on wall thinning and crack size are developed to preclude gross rupture. Gross wall thinning criteria is bas ad on ASME Section VIII, which is the design code for the heat exchanger. Local wall thinning evaluation is based on ASME Code Case N-480. ASME Section XI criteria, with the factors of safety recommended by Regulatory Guide 1.121 are used to develop the allowable crack size criteria. Normal operating conditions (pressure, dead weight, and hydraulic drag) are considered with seismic and water hammer accident conditions. Both the wall thinning and crack size criteria are developed for the end-of-evaluation period. Allowances for corrosion, wear, or crack growth have not been included in this analysis.

Structurally, the tubing is over designed and can tolerate large defects with adequate margins against gross rupture. The structural margins of heat exchanger tubing are evident by contrasting the tubing's structural capacity, per the ASME Code, with it's operating conditions/configuration:

- 3600 psig capacity versus 200 psig actual normal operating pressure;

- $0.0037^{\prime \prime}$ rninimum wall thickness versus $0.049^{\prime \prime}$ actual wall thickness;

- localized wall thinning below 0.0037" is allowable;

- large crack lengths (greater than one-half of the circumference) are allowable. 


\section{INTRODUCTION AND CONCLUSIONS}

Twelve process water heat exchangers are designed to remove heat generated in the reactor lank. Each heat exchanger has approximately $9000,1 / 2^{\prime \prime}$ diameter $\times 0.049^{\prime \prime}$ thick tubes. Minimum structural tubing requirements and the leak rate through postulated tubing defects are developed in this report. A comparison of the structural requirements and the defect size calculated to produce leak rates of $0.5 \mathrm{lbs}$./day demonstrate adequate structural margins against gross tube rupture.

\subsection{Structural Design Capacity}

Structurally, the heat exchanger tubing is over designed. The allowable normal operating pressure for the rubing, using ASME Section VIIl, Division 2 and minimum material properties, is 3600 psig. Normal operating pressure is approximately $200 \mathrm{psig}$ and the design pressure is 300 psig. For a water hammer transient, the allowable pressure is 4300 psig. The maximum analyzed water hammer transient has a peak pressure near the operating pressure (200 psig).

\subsection{Structural Requirements for Minimum Thickness}

The minimum wall thickness for the design pressure, using ASME Section VIII, Division 2 and minimum material properties, is $0.0037^{\prime \prime}$. Water hammer transients on the tube side require an additional $0.001^{\prime \prime}$ of wall thickness for each 100 psig of pressure over 300 psig. The maximum analyzed water hammer transient has a peak pressure near the operating pressure (200 psig). Water hammer will not burst the heat exchanger tubing.

ASME Code Case N-480 is used to determine the allowable wall thickness for a pit or wear scar. The minimum wall thickness for a wear scar or pit is $0.002 "$, with a $1 / 32^{\prime \prime}$ width less than $0.0037^{\prime \prime}$ thick. Wider wear scars require thicker material.

\subsection{Structural Requirements for Maximum Flaw Size}

The ASME Section XI limit load criteria in Appendix C-3320 and C-3340 are used with Regulatory Guide 1.121 factors of safety ( 3 for normal operation and 1.5 for accident conditions) to determine the allowable sizes of postulated circumferential and axial flaws. Allowable flaw sizes are calculated for 1) the nominal wall thickness, 0.049 inches; and 2) a re gion previously thinned by wastage, with a postulated wall thickness of 0.025 inches. The non-mechanistic combination of wastage and cracking is used to determine the sensitivity of the allowable flaw length to variations in wall thickness. Both throughwall and part throughwall flaws are analyzed.

The allowable size of circumferential throughwall flaws is greater than $50 \%$ of the tubing circumference $\left(\approx 0.8^{\prime \prime}\right)$, for tubing $0.025^{\prime \prime}$ and thicker. The allowable depth for $360^{\circ}$ circurnferential part throughwall flaws is $90 \%$ of the remaining tubing thickness, for tubing $0.025^{\prime \prime}$ and thicker. The allowable size of circumferential flaws is relatively insensitive to variations in the wall thicknesses between $0.049^{\prime \prime}$ and 0.025 ".

The allowable length of axial flaws is sensitive to variations in the wall thickness. The allowable length of a throughwall axial flaw is 2 " for $0.049^{\prime \prime}$ thick tubing and 0.74 " for 0.025 "thick tubing. Interpolation can be used to determine the allowable lengths for intermediate tubing thicknesses. "1he allowable depth of 2 " long part throughwall axial flaws is $85 \%$ for tubing between 0.049 " and $0.025 "$. 


\subsection{Reference Leakage Size Flaw and Structural Margins}

For the $0.049^{\prime \prime}$ thick tubing, the crack lengths required to obtain $0.5 \mathrm{lbs}$./day leakage are between 0.4 " and 0.6 " for both circumferential and axial flaws. The structural margins on stress are greater than 3 while the margin on crack length is 1.9. These margins are adequate and indicate that the tubing will leak without breaking. This calculation is supported by the past 37 years of reactor operating history, in which 63 leaks were detected in the heat exchanger tubing without a double ended guillotine break.

\subsection{Inspection Acceptance Criteria}

The structural and operation requirements are synthesized into the ASME Section XI compatible end-of-evaluation period inspection acceptance criteria in Table 11. This criteria covers general wall thinning, local wall thinning, and cracking. Allowances for further wall thinning and/or crack growth are not included in this criteria. This acceptance criteria is intended to 1) prevent gross rupture, and 2) prevent leakage, based on the configuration at the end of an evaluation period. 


\section{COMPONENT DESCRIPTION}

The process water heat exchangers are designed to remove heat generated in the reactor tank. The once-through, counter flow type heat exchangers are supported horizontally on the -2(1) level, Figure 1. Pressures and temperatures are given in Table 1 for both normal operation and design conditius.

Each heat exchanger consists of a 7'-3 1/2" diameter cylindrical shell attached at each end to either a double or single tube sheet. The overall length of the shell section is $29^{\prime} 2-1 / 2^{\prime \prime}$. Heads at each end of the shell are bolted to the process water piping and are attached to the tube sheet by 84 staybolts. Cooling water flows into and out of the shell through nozzles near each end of the shell. Inside the shell, the cooling water flows around 6 flow reversing baffles and 6 or 12 intermediate baffles. A diffuser plate and strainer are located at the cooling water inlet.

Inside the shell section are approximately 9000, 1/2" diameter $\times 0.049$ " thick (18 gauge) tubes which span axially between baffles [18]. Each of the approximately 9000 tubes are attached to the tube sheet by expansion (hydraulic or rolled) and seal welding. The bottom and top rows of tubes are plugged. 'The nominal spacing between adjacent baffle plates varies from 16.6 to 24.9 inches depending on the type of heat exchanger. Inside most of the tubes are 0.296" diameter concentrically supported core rods.

The original design of the shells and heads, Type "A", was by Foster Wheeler and utilized double tube sheets at each end of the shell, six intermediate baffles, and a solid diffuser plate without a CWS inlet strainer. Type 304 stainless steel was used for the tubes, shell, head, and tube sheets in the Type A design. Both seamless and welded Type 304 stainless steel tubes may have been used. The Type A heat exchangers were constructed to the 1949 ASME Section VIII design code.

Several modifications were made to the original design (Type " $A$ ") heat exchangers, prior to 1966 , to resolve operational problems. The heat exchangers were completely overhauled and rotated, tubes were plugged in critical positions, a perforated cooling water inlet diffuser plate and strainer were installed, and an inhibitor system was installed between the double tube sheets. All gaskets and O-rings exposed to moderator (head-to-tube sheet and head to staybolt) were eliminated by using a welded boss closure around the staybolt and a

\section{Table 1. Heat Exchanger Operating and Design Conditions}

\begin{tabular}{llllll} 
& & PW Inlet & PW Outlet & CW Inlet & CW Outlet \\
\cline { 3 - 6 } Temperature & Operating & $131^{*}$ & $79^{*}$ & $55^{*}$ & $109^{*}$ \\
$\left.{ }^{\circ} \mathrm{F}\right)$ & Design & 250 & 250 & 200 & 200 \\
Pressure & Operating & $203^{* *}$ & 163 & 50 & 20 \\
(psig) & Design & 300 & 300 & 150 & 150 \\
\cline { 2 - 5 } & Heat Exchanger End & Hot & Cold & Cold & Hot
\end{tabular}

* Actual operating data obtained form the Reactor Control Computer RMS (Reactor Monitoring System) $1308 \mathrm{MW}, \mathrm{RMS}, 3 / 11 / 88$, K13.2.

**Maximum occurring during start-up of the pump's AC motor before opening the rotovalves is 267 psig for approximately 6 seconds $+/-3$ sec. [3] 
welded omega seal to join the head to the tube sheet. The head vent and drain lines were relocated. Head tlange bolt holes were filled with plugs and seal welded.

Replacement heat exchangers purchased in the early 1980's from Mitsui and Hitachi are designated as Type B. These theat exchangers are based on the original Type A design, incorporating the changes made to the Type A design during the 1960 heat exchanger overhatul program. The double tube sheet on the Type A design was consolidated into a single tube sheet on the Type B design. Twelve intermediate baffles are used on the Type B design versus six on the Type A design. Additionally, the tubing and tube sheets in the Type B design are made of Type $316 \mathrm{~L}$ stainless steel, while the shell, nozzles, distributor plates, and baffles are made of Type 304L stainless steel. Only seamless Type $316 \mathrm{~L}$ stainless steel tubes are used in the Type B design.

Replacement heat exchangers purchased in the mid 1980's from Nooter use Hitachi heads and are designated as Type $C$. Geometrically, the Type $B$ and $C$ heat exchangers are aquivalent. The Type $C$ heat exchangers have seamless Sea-Cure ${ }^{1}$ tubing, while the Type $A$ and $B$ designs used Type 304 and $316 \mathrm{~L}$ stainless steels, respectively. The Types $B$ and $C$ replacement heat exchangers were built in accordalce with the 1980 ASME Section VIII and 1968 TEMA design codes.

Table 2 lists the various materials of construction for the different types of heat exchangers. Table 3 provides the heat exchanger purchase information including date received, serial numbers, vendor and BPF number. The materials of construction for the components of the individual heat exchangers installed in SRS K reactor, as well as the corresponding serial numbers, are listed in Table 4.

Sea-Cure is a ferritic stainless steel manufactured by the Trent Tube Division of Cruciable Steel. Trent Sea-Cure stainless steel is approved for ASME Boiler and Pressure Vessel Code and is included in Section VIII Division 1, Table UHA-23 and in Code Cases 1900 and 1922 . Sea-Cure tubing is is ferritic stainless steel produced by either argon-oxygen decarburization (AOD) refining or vacuum-oxygen decarburization (VOD), to achieve a low carbon and nitrogen interstitial content. The steel is also stabilized with titanium and/or niobium to provide optimum weld and annealing sensitization resistance. Alloying additions of chromium, molybdenum, and nickel provide an cptimum combination of corrosion resistance and improved mechanical properties. Nickel additions reduce the ductile-brittle transition temperature to below $20 \mathrm{C}(-10 \mathrm{~F})$. Sea-Cure stainless is highly resistant to localized pitting and crevice corrosion and highly resistant to stress corrosion. 
Table 2. Heat Exchanger Materials of Construction

\begin{tabular}{lccc} 
Description & \multicolumn{3}{c}{ Heat Exchanger Materials of Construction } \\
\cline { 2 - 4 } & Type A & Type B & Type C \\
\hline Head and Head Flange & Type 304 & Type 304 or 304-L* & Type 304-L \\
Shell & Type 304 & Type 304-L & Type 304-L \\
Tube Sheet(s) & Type 304 & Type 316-L & Type 316-L \\
Tube & Type 304 & Type 316-L & Sea Cure \\
Staybolt & Type 303 & Type 303 & Type 303 \\
Omega Seal & Type 304-I. & Type 304-L & Type 304-L \\
Bolt Hole Plugs & Type 304-L & Type 304-L & Type 304-L \\
12" Flange & Type 304-L & Type 304-L & Type 304-L \\
Core Rod & Type 304-L & Type 304-L & Type 304-L \\
Boss Closure Assembly & Type 304-L & Type 304-L & Type 304-L
\end{tabular}

* Eighteen Type B heads were salvaged from Type A heat exchangers, and are Type 304 stainless steel. Heads fabricated for the Type B heat exchangers are Type 304-L

Table 3. Heat Exchanger Purchase Information

\begin{tabular}{|c|c|c|c|c|}
\hline Date Rec'd & Type & Serial No's & Vendor & BPF Number \\
\hline 1953.54 & A & $\begin{array}{l}\mathrm{OH}-7249 \text { to } \\
\mathrm{OH}-7260\end{array}$ & Foster Wheeler & 120020 \\
\hline $1954-56$ & $A$ & $\begin{array}{l}\text { OH-7811 to } \\
\text { OH-7848 }\end{array}$ & Foster Wheeler & 120221 \\
\hline 1954.56 & A & $\begin{array}{l}44344 \text { to } \\
44355\end{array}$ & $\begin{array}{l}\text { American } \\
\text { Locomotive }\end{array}$ & 120236 \\
\hline 1962 & A & $\begin{array}{l}58-9478 \text { to } \\
58-9479\end{array}$ & Foster Wheeler & 211069 \\
\hline 1963 & A & $\begin{array}{l}58-9509 \text { to } \\
58-9512\end{array}$ & Foster Wheeler & 211259 \\
\hline 1983 & B & $\begin{array}{l}1315-120-1 \text { to } \\
1315-120-12\end{array}$ & Mitṣui & 213314 \\
\hline 1983 & B & $\begin{array}{l}105-999-1 \text { to } \\
105-999-2\end{array}$ & Hitachi & 213501 \\
\hline 1983 & B & $\begin{array}{l}105-150-1 \text { to } \\
105-150-4\end{array}$ & Mitsui & 213225 \\
\hline 1987 & C & $\begin{array}{l}105-999-3 \text { to } \\
105-999-10\end{array}$ & $\begin{array}{l}\text { Nooter-Shells } \\
\text { Hitachi-Heads }\end{array}$ & $\begin{array}{l}216254 \\
216386\end{array}$ \\
\hline
\end{tabular}




\section{Table 4. Materials of Construction for the $K$ Reactor} Heat Exchangers In Service .- 2/1/92

\begin{tabular}{|c|c|c|c|c|c|c|c|}
\hline Location & I.D. & Type & Head & Shell & Tubes & Tube & Sheet \\
\hline IA & $\mathrm{OH} 7831$ & A & 304 & 304 & 304 & 304 & Double \\
\hline $1 \mathrm{~B}$ & $105-999-9$ & $\mathrm{C}$ & $304-\mathrm{L}$ & $304-\mathrm{L}$ & Sea Cure & $316-\mathrm{L}$ & Single \\
\hline $2 \mathrm{~A}$ & $\mathrm{OH} 7839$ & A & 304 & 304 & 304 & 304 & Double \\
\hline $2 \mathrm{~B}$ & $\mathrm{OH} 7825$ & A & 304 & 304 & 304 & 304 & Double \\
\hline $3 \mathrm{~A}$ & $\mathrm{OH} 7847$ & A & 304 & 304 & 304 & 304 & Double \\
\hline $3 B^{*}$ & $105-999-7$ & $\mathrm{C}$ & $304-\mathrm{L}$ & $304-\mathrm{L}$ & Sea Cure & $316-\mathrm{L}$ & Single \\
\hline $4 A^{*}$ & $105-999-8$ & C & $304-\mathrm{L}$ & $304-\mathrm{L}$ & Sea Cure & $316-\mathrm{L}$ & Single \\
\hline$+B^{*}$ & $105-999-5$ & C & $304-\mathrm{L}$ & $304-\mathrm{L}$ & Sea Cure & $316-\mathrm{L}$ & Single \\
\hline $5 \mathrm{~A}$ & 44352 & A & 304 & 304 & 304 & 304 & Double \\
\hline $5 \mathrm{~B}$ & 44344 & A & 304 & 304 & 304 & 304 & Double \\
\hline $6 \mathrm{~A}$ & $105-999-3$ & C & $304-\mathrm{L}$ & $304-\mathrm{L}$ & Sea Cure & $316-\mathrm{L}$ & Single \\
\hline $6 \mathrm{~B}$ & $1315-120-11$ & B & 304 & $304-\mathrm{L}$ & $316-\mathrm{L}$ & $316-\mathrm{L}$ & Single \\
\hline
\end{tabular}




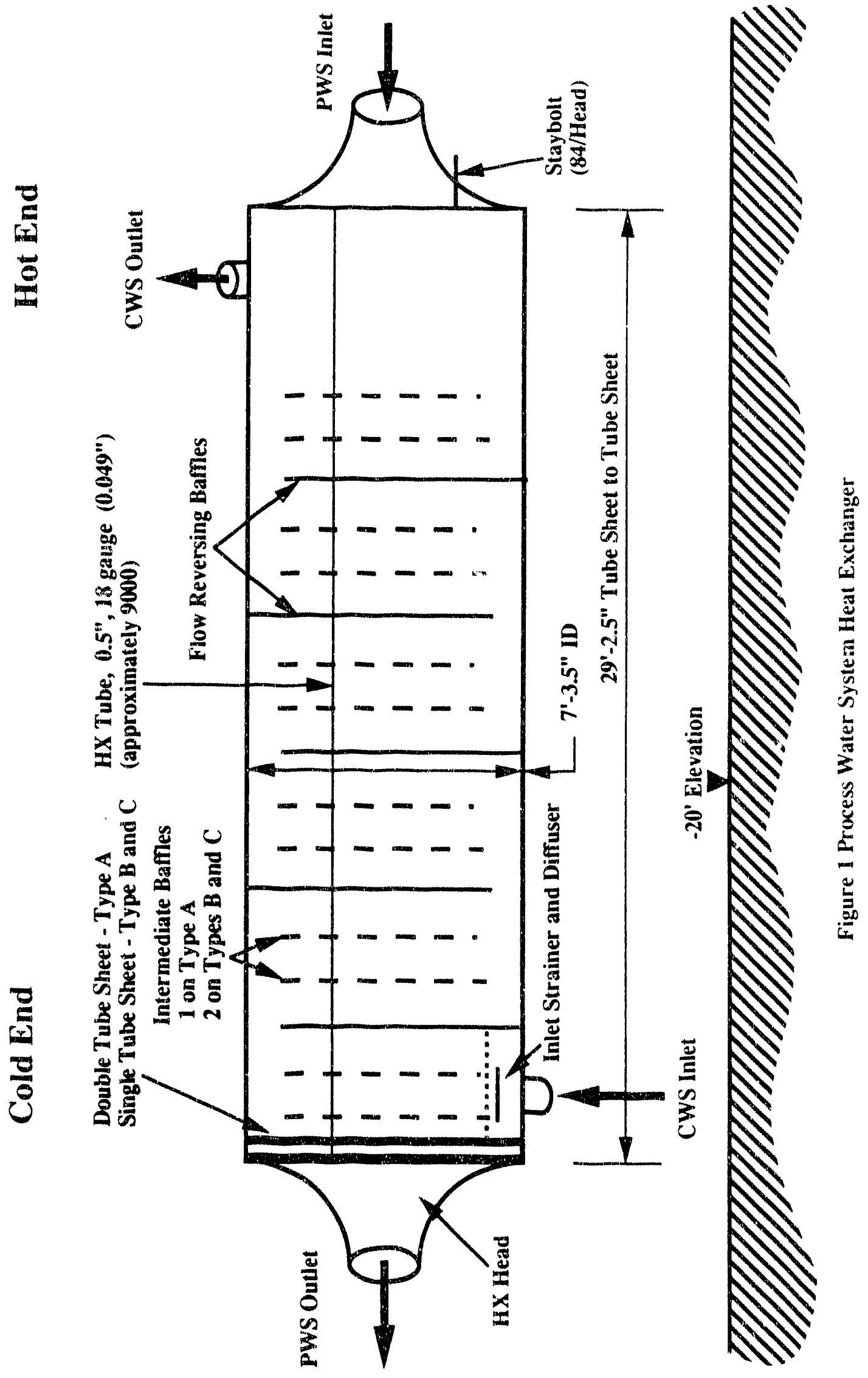




\section{OPERATING HISTORY}

The operating history of the Savannah River Site Process Water System (PWS) heat exchanger tubes was reviewed to determine critical or suspect areas of the tube bundle where degradation is most likely to $\alpha$ cur [1]. During the past 37 years of reactor operation, 63 heat exchangers were replaced because of tube leaks. Thirty seven of the tube leaks were due to mechanical degradation, iwenty three were due to corrosion, and the leak mechanism is unknown in three instances!. No rupture equivalent to a complete circumferential severance has occurred in the operating history of the SRS reactor PWS heat exchangers. A hypothetical complete severance of the tube (neglecting the core rods) is an accident scenario considered in the SRS K Reactor Safety Analysis Report.

\subsection{Mechanical Degraúation}

Twenty four heat exchangers leaked besause of rube wear against baffle plates prior to 1965. This wear occurred primarily in the bottom row tubes, and a few at corner tubes adjacent to the stell, where the inlet cooling water velocity was high. Nine heat exchangurs leaked due to wear from a foreign body (plastic bris,les, wire etc.). Two instances of vibration fatigue, one instance of core rod vibration, and one instance of tie rod spacer wear have also been observed. Except for the core rod vibration, all of the mechanical degradation leaks have ncurred before 1965.

The heat exchangers were given a complete overhaul between June 1964 and November 1966. During the overhaul, a perforated cooling water inlet diffuser plate and strainer were added to the heat exchanger, which reduced the inlet cooling water velocity and prevented large items from impacting the tubes. Addicionally, the bottom row of tubes and select tubes on the edge of the tube bundle were plugged. Reducing the cooling water velocity eliminated the vibration problems. The potential for wear from foreign bodies was minimized by reducing the screen size in the cooling water (186) basin to 0.25 ", installing the CWS inlet strainer and procedural changes.

The only tube leak due to mechanical degradation since 1966 occured in 1972 when a core rod moved out of the tube and entered a septifoil line where flow induced vibration caused the rod to wear through the tube. In 1990, all core rods aligned with the septifoil piping underwent a pull test to ensure that there was adequate resistance to prevent movement of the core rod into the septifoil line.

\subsection{Corrosion}

Several instances of chloride stress corrosion were noted between the double tube sheets in the leak collection spaces prior to 1965. The heat exchangers were reversed to extend their life and an inhibitor system was installed to circulate a phosphate solution through the leak collection space to control the corrosion. The Type $B$ and $C$ heat exchangers have a single tube sheet and do not require the corrosion inhibitor system.

1 Tube leaks with an unknown cause occured in the $\mathrm{L}$ Reactor on 6/57 and in the $\mathrm{K}$ reactor on $5 / 63$ and $12 / 91$. The investigation of the $12 / 91$ tube leak is in progress $(2 / 14 / 92)$. 
Beginning in the 1970's, several instances of stress corrosion cracking at tube to tube sheet junction were noted along with pitting corrosion. The tubing materials in the Types B and $C$ heat exchangers were changed from Type 304 stainless steel to Type 316L stainless steel and Sea Cure to prevent corrosion. All of the tube leaks due to corrosion have occured in Type A heat exchangers. 


\section{STRUCTURAL REQUIREMENTS}

Limits on wall thinning and crack size are developed in this section to preclude gross rupture. Gross wall thinning criteria is based on ASME Section VIII Division 2 while local wall thinning is based on ASME Code Case N-480. ASME Section XI criteria, with the factors of safety recommended by Regulatory Guide 1.121 are used to develop the crack. size criteria. Both the wall thinning and crack size criteria are developed for the end-ofevaluation period. Allowances for corrosion or crack growth have not been included in this analysis.

\subsection{Applied Loadings}

\section{Self Weight}

The weight of the $0.5^{\prime \prime}$ outer diameter by $0.049^{\prime \prime}$ thick tubing (Metal Area $=0.0694 \mathrm{in}^{2}$ ), 0.296" diameter core rod (Metal Area $\left.=0.0688 \mathrm{in}^{2}\right)$ and the weight of the $\mathrm{D}_{2} \mathrm{O}(69.33 \mathrm{pcf})$, neglecting the buoyancy of river water on the shell side is

$$
w=\frac{490 \mathrm{pcf}}{12^{3} \mathrm{cu} \mathrm{in} / \mathrm{cf}}(0.0694+0.0688) \mathrm{in}^{2}+\frac{69.333 \mathrm{pcf}}{12^{3} \mathrm{cu} \mathrm{in} / \mathrm{cf}}(0.1269-0.0688) \mathrm{in}^{2}=0.0415 \mathrm{lbs} / \mathrm{in}
$$

The tubes span horizontally between baffles, with a maximum center to center spacing of 24.9". The maximum bending moment due to self weight is

$\mathrm{M}_{\mathrm{dl}}=\frac{0.0415 \mathrm{lbs} / \mathrm{in}(24.9 \mathrm{in})^{2}}{12}=2.14 \mathrm{in} \mathrm{lb}$

\section{Internal Pressure}

The pressure resisted by the tubing is the difference between internal and external pressure. During normal operation, the internal pressure at the heat exchanger inlet is $203 \mathrm{psig}$ and the corresponding external pressure is $2 U$ psig. During pump start up, the internal pressure may be as high as $267 \mathrm{psig}$ for a short period of time. "This analysis conservatively neglects the shell side pressure and uses the design pressure of $300 \mathrm{psig}$ as the normal operating pressure. This assumption bounds the hydraulic loadings specified in Regulatory Guide 1.121.

At the tube sheet and baffles the radial expansion of the tube due to internal pressure is restrained by the diameter of the hole ${ }^{l}$ as shown in Figure 2. The unrestrained radial expansion, due to internal pressure, $P$, is

$\Delta R=\frac{P r^{2}}{E t}$

Solving for the shear, $\mathrm{Q}$, and moment, $\mathrm{M}_{\mathrm{v}}$ in the wall of the tube due to the radial constraint imposed by the tube sheet, using ASME Section VIII, Division 2, Appendix 4, Article 4.231 for long tubes, yields

1 The tube sheet hole is between 0.01 " to $0.022^{\prime \prime}$ larger than the nominal tube diameter. Recognizing the tolerances in the tube diameter, nube roundness, tube straightness, hole diameter, and hole location; the gap between the tube and tube sheet is conservatively neglected. 


$$
\begin{aligned}
& w(x)=\frac{Q 0}{2 \beta^{3} D} f_{1}(\beta x)+\frac{M o}{2 \beta^{2} D} f_{2}(\beta x) \\
& \frac{\theta(x)}{\beta}=\frac{-Q 0}{2 \beta^{3} D} f_{3}(\beta x)-\frac{2 M o}{2 \beta^{2} D} f_{1}(\beta x)
\end{aligned}
$$

Where $\beta=\sqrt[4]{\frac{3\left(1-v^{2}\right)}{t^{2}(R+t / 2)^{2}}}, D=\frac{E t^{3}}{12\left(1-v^{2}\right)}, E$ is the elastic modulus, 27,400,000 psi, $v$ is Poissons ratio, $0.3, \mathrm{R}$ is the mean radius, $t$ is the thickness, Mo and $\mathrm{Qo}$ are the bending moment and shear in the pipe wall at the baffle plate or tube sheet. At the tube sheet and baffles, $x=(), w(0)=-\Delta R, \theta(0)=0$ and $f_{1}(\beta x)=f_{2}(\beta x)=f_{3}(\beta x)=1$. Solving for the maximum moment Mo yields

$M_{0}=\frac{P R^{2}}{E I} 2 \beta^{2} D$

And the maximum bending stress in the wall is

$\sigma= \pm \frac{6}{t^{2}} \frac{P R^{2}}{E t} 2 \beta^{2} D$

Note that the bending stress is classified as a secondary stresses because it is deformation controlled. The shear stress is small compared to the bending stress and is neglected.

\section{Hydraulic Drag}

On the secondary side of the heat exchanger, 14,000 gpm (31.2 cfs) of cooling water flows through the tube bundle, creating a lateral loading (drag) on each of approximately 9000 tubes (number of tubes varies for Types $A, B$ and $C$ ). The $0.5^{\prime \prime}$ OD tubes have a triangular pitch of $0.75^{\prime \prime}$ and a spacing between tubes of $0.25^{\prime \prime}$. The distance between flow reversing baffles is 49.8" and the width of the top and bottom row of tubes is 62.6". The cooling water velocity between tubes is

$V=\frac{31.2 \mathrm{cfs} \times 144 \mathrm{in}^{2} / \mathrm{ft}^{2}}{62.6^{\prime \prime}(.25 / .75) 49.8^{\prime \prime}}=4.3 \mathrm{fps}=51.9 \mathrm{ips}$

The hydraulic diameter of the space between tubes is [19]

$D_{e}=\frac{2 X Y}{X+Y}=\frac{2 \times 0.25 \times 24.9}{0.25+24.9}=0.50^{\prime \prime}$

And the Reynolds number for flow between tubes is

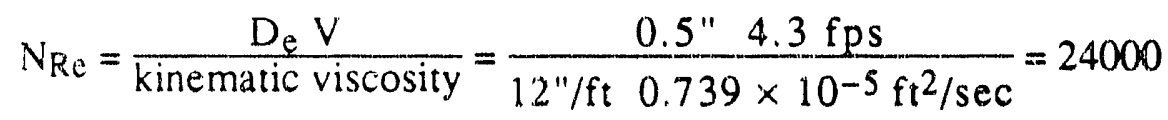

The drag on a single tube in an infinite medium is expressed by 
$w=\frac{C_{D} \text { Area Density V2 }}{2 \mathrm{~g}}=\frac{C_{D}(0.5 / 12) \mathrm{ft} 62.4 \mathrm{pcf}(4.3 \mathrm{fps})^{2}}{2 \times 32.2 \mathrm{ft} / \mathrm{sec}^{2}}=0.746 \mathrm{CD}_{\mathrm{D}} \mathrm{lbs} / \mathrm{ft}$

A single tube in an infinite medium with a Reynolds number of 24000 has laminar flow with a coefficient of drag near 1 . In the heat exchinger, the cooling water flows around an deflector plate, through a strainer before it flows through the tube bank. The first row of tubes in the tube bank are either solid bars or plugged tubes. For tubes inside the heat exchanger tube bank, the flow is trip turbulent and a drag coefficient corresponding to fully turbulent flow is appropriate. For turbulent flow of a long isolated tube the drag coefficient is $C_{D}=0.33$ [20] and the loading on the pipe is $w=0.021 \mathrm{lbs} / \mathrm{inch}$. The maximum moment due to hydraulic drag is

$M_{\mathrm{drag}}=\frac{0.021 \mathrm{lbs} / \mathrm{in}(24.9 \mathrm{in})^{2}}{12}=1.09 \mathrm{in} \mathrm{lb}$

Since the velocity of the cooling water in the heat exchanger is constant, the total drag force is related to a pressure drop across the heat exchanger. Summing the drag forces on 8800 tubes

$F_{\text {drag }}=0.021 \mathrm{lbs} / \mathrm{in} \times 12 \mathrm{in} / \mathrm{ft} \times 29^{\prime} \times 8800$ rubes $=64,000 \mathrm{lbs}$

The theoretical pressure drop across the heat exchanger resulting from the tube drag forces is

$\Delta p=\frac{64000}{\pi 12^{2}}=140 \mathrm{psig}$

Since the total pressure drop across the heat exchangers is only $30 \mathrm{psig}$, which is far less than the theoretical pressure drop based on the calculated drag force, then the calculated drag force is conservative.

\section{Flow Induced Vibration}

Flow induced vibration was examined in Calc. M-CLC-K-00225 [6]. The natural frequency of a single heat exchanger tube and the surrounding fluid is 147 hertz, which is far from the vortex shedding frequency of 27 hertz. Thus, vortex shedding will not excite a tube harmonic and vibration amplitude due to flow induced vibration is a minimum. This is consistent with commercial experience which has shown that vortex shedding does not generally produce large amplitude tube vibrations in tube arrays with a tube spacing of 1.5 tube diameters or less because the proximity of the tubes causes regular vortex shedding to degenerate into broad band turbulence $[5,11]$. The nube spacing in the SRS heat exchangers is 1.5 tube diameters. Fluid elastic vibration of the SRS heat exchanger tubing was examined in Reference 23 which concluded that the heat exchanger tubes are stable.

Type A heat exchangers did experience vibration failures prior to the complete overhaul that was finished in 1966. Prior to the overhaul, the heat exchangers had a solid deflector plate without a strainer. At the edge of the solid deflector plate the water velocity was very high causing vibration problems. These vibration problems were solved with the introduction of the perforated cooling water inlet diffuser plate and strainer, which reduced the peak water velocity at the edge of the deflector plate. Types $B$ and $C$ heat exchangers also have a perforated cooling water inlet diffuser plate and strainer. Operating experience since 1966 
has demonstrated that flow induced vibrations on the shell side are negligible. Thus, loads due to flow induced vibration, on the shell side, are not considered.

One instance of core rod vibration occurred on the tube side since the overhaul. A core rod moved out of the tube and entered a septifoil line where flow induced vibration caused the rod to wear through the tube. In 1990, all core rods aligned with the septifoil piping underwent a pull test to ensure there was adequate resistance to prevent movement of the core rod into the septifoil line. Thus, loads due to flow induced vibration, on the tube side, are not considered.

\section{Tube Side Water Hammer}

Water hammer in the PWS was examined in References 12 and 13. The maximum calculated pressure on the tube side of the heat exchanger is 195 psia and occurs from closing the rotovalve in 8.5 seconds $^{l}[12,13]$. This pressure is less than the 300 psig design pressure discussed previously and water hammer transient pressure on the inside of the heat exchanger tubes is nominal.

A non-mechanistic watei hammer pressure of 450 psig is assurned in this analysis to determine the sensitivity of (1) the minimum wall thickness; and (2) the allowable flaw length; to water hammer transients. Pressure on the shell side of the tube is conservatively neglected for this non-mechanistic accident condition.

\section{Shell Side Water Hammer}

Water hammer in the CWS was examined in References 13,14 and 15. The peak water hammer pressure on the shell side of the heat exchanger is $182 \mathrm{psia}$, which occured during the 1989 incident in the $190 \mathrm{~K}$ pumphouse. A typical pressure pulse in the heat exchanger has a pressure rise $(\Delta \mathrm{p})$ of $110 \mathrm{psi}$ in about 0.1 second, as shown in Figure B3 of Reference 15 . Bending stresses in the tube are caused by differential pressure across the diameter of a tube. Pressure is transmitted at the speed of sound $(\approx 2000 \mathrm{fps})$, thus the differential pressure acting on a $0.5^{\prime \prime}$ diameter tube is

$\Delta p=\frac{110 \mathrm{psi}}{0.1 \text { second }} \times \frac{0.5^{\prime \prime}}{2000 \times 12 \mathrm{ips}}=0.023 \mathrm{psi}$

and the moment due to water hammer, with a dynamic load amplification factor of 2 is

$\mathrm{M}_{\text {water hammer }}=\frac{0.023 \mathrm{lbs} / \mathrm{in} \times 0.5 \mathrm{in}(24.9 \mathrm{in})^{2}}{12} \times 2=1.19 \mathrm{in} \mathrm{lb}$

This water hammer scenario occured when the ECS cross tie header was pressurized without flow to the heat exchangers. Thus $\mathrm{M}_{\mathrm{drag}}$ is not combined with $\mathrm{M}_{\text {water hammer }}$

\section{Seismic Loadings}

The seismic loading on a heat exchanger tube was evaluated in Calc. M-CLC-K-C0225 [6]. The natural frequency of a single heat exchanger mbe $\left(0.5^{\prime \prime} \mathrm{OD}, 0.049^{\prime \prime}\right.$ thick) and the surrounding fluid is 147 hertz, while the natural frequency of the heat exchanger is 8.6 hertz, yielding a maximum tube moment of $M_{\text {seismic }}=0.662$ in lbs [6]. Reducing the

1 Recent $\mathrm{K}$ reactor valve test indicated that the rotovalve closure time is between 13.7 and 15.9 seconds [17]. 
tube's wall thickness will reduce the tubes natural frequency. At $25 \%$ of the original wall thickness, the tube natural frequency is reduced to 73 hertz, but the seismic response of the tube is essentially the same because the systems response is dominated by the heat exchangers natural frequency. Thus, a seismic moment of 0.662 in lbs is used regardless of the wall thickness.

\section{Thermal Stress due to Differential Temperature Across the Wall Thickness}

The temperature differential between the primary and secondary loops is approximately $25^{\circ} \mathrm{F}$. [RMS DATA $1600 \mathrm{MW}$ at $3 / 11 / 88 \mathrm{~K}-13.2$ ] Conservatively adding $5^{\circ} \mathrm{F}$ for local variations in the tube temperature, the secondary bending stress in the tube wall becomes 1211

$\sigma_{h}=\sigma_{1}=0.5 \Delta \mathrm{T} \frac{\alpha \mathrm{E}}{1-v}= \pm 5226 \mathrm{psi}$

Where $\alpha$ is the coefficient of thermal expansion, $\alpha=8.9 \times 10^{\circ 6} /{ }^{\circ} \mathrm{F}$, $\mathrm{E}$ is the elastic modulus, $E=27,400,000 \mathrm{psi}$, and $v$ is Poissons ritio, $v=0.3$. The stresses are in tension on the outer diameter and compression on the inner diameter. Calc. M-CLC-K-00225 [6] calculated thermal stresses less than one-half of the values calculated herein, indicating that the current values are conservative.

\section{Differential Thermal Expansion of the Tube and Heat Exchanger Shell}

The mean temperature of the tubes is approximately $15^{\circ} \mathrm{F}$ hotter than the heat exchanger shell. Thus, the tubes are in axial compression due to thermal expansion. Assuming that the heat exchanger shell is prefect rigid, then the secondary expansion stress is

$\sigma=\alpha E \Delta T=-3660$ psi

Including the flexibility of the heat exchanger shell reduces the secondary expansion stress 10

$\sigma=\left(1-\frac{A_{\text {lubes }}}{A_{\text {tubes }}+A_{\text {shell }}}\right)(-3660)=-730$ psi

Where the area of the tubes is $8800\left(0.0694 \mathrm{in}^{2}\right)$ and the area of the shell is $138 \mathrm{in}^{2}$. Since this thermal stress reduces the longitudinal pressure stress $(P R / 2 t)$ it is conservatively neglected.

\section{-Differential Radial Thermal Expansion of the Tube and Baffle Plate}

Since the baffle plates are in contact with the tubes, the baffle plates are assumed to have the same ternperature as the mean tube temperature. Thus, secondary bending stresses in the wall of the tubing from baffle restraint are not considered

\subsection{Minimum Wall Requirements for Gross Thinning}

The tubing was originally designed to the ASME Section VIII, Division 1 code. The minimum required wall thickness is determined using the Division 2 rules, given in Appendix 4, Figure 4-130.1. The primary membrane stress intensities ( $\left.P_{M}\right)$ for normal operating conditions are 
$\sigma_{\mathrm{h}}=\frac{\mathrm{PR}}{\mathrm{t}}<\mathrm{Sm}$

$\sigma_{1}=\frac{P R}{2 t}+\frac{M_{d l}+M_{d r a g}}{Z}<S m$

Where $R$ and $t$ are the mean radius and thickness respectively. The section modulus, $Z$, is conservatively calculated by assuming that all of the wall thinning occurs on the outer fibers. Sm is the ASME Section VIII design stress intensity given in Table 5.

Primary membrane stress intensities $\left(\mathrm{P}_{\mathrm{M}}\right)$ for accident conditions are

$\sigma_{\text {h seismic }}=\sigma_{h \text { SSWH }}=\frac{P_{300 R}}{t}<k$ Sm

$\sigma_{\mathrm{h}} \mathrm{TSWH}=-\frac{\mathrm{P}_{450} \mathrm{R}}{\mathrm{l}}<\mathrm{kSm}$

$\sigma_{1 \text { seismic }}=\frac{P_{30 \ell} R}{2 t}+\frac{M_{d l}+M_{d r a g}+M_{\text {seismic }}}{Z}<k$ Sm

$\sigma_{\text {ISSWH }}=\frac{P_{300} R}{2 t}+\frac{M_{d l}+M_{\text {water hammer }}}{Z}<k$ Sm

$\sigma_{\text {I TSWH }}=\frac{P_{450} R}{2 t}+\frac{M_{d l}+M_{d r a g}}{2}<k S m$

Where $\mathrm{k}$ is equal to $1.2, \sigma \mathrm{l}$ seismic is the longitudinal stress due to seismic loading, $\sigma_{I S S W H}$ is the longitudinal stress due to the shell side water hammer and $\sigma_{1}$ TSWH is the longitudinal stress due to the non-mechanistic tube side water hammer. The pressure $\mathrm{P}$ or $\mathrm{P}_{300}$ is the normal operating pressure, 300 psig. $\mathrm{P}_{450}$ is the non-mechanistic tube side water hammer accident condition pressure of 450 psig.

Table 5 ASME Section VIII design Stress Intensity (psi) at $200^{\circ} \mathrm{F}$ [7]

$\begin{array}{cccccc}\begin{array}{c}\text { Material } \\ \text { Welded or } \\ \text { Seamless }\end{array} & \begin{array}{c}\mathbf{3 0 4} \\ \text { Welded }\end{array} & \begin{array}{c}\mathbf{3 0 4} \\ \text { Seamless }\end{array} & \begin{array}{c}\mathbf{3 1 6 L} \\ \text { Seamless }\end{array} & \begin{array}{c}\text { Sea-Cure } \\ \text { Welded }\end{array} & \begin{array}{c}\text { Sea-Cure } \\ \text { Seamless }\end{array} \\ \begin{array}{c}\text { S m } \\ 1.5 \mathrm{Sm}\end{array} & 25.5 & 20 & 16.7 & 24.1 & 28.3 \\ 3 \mathrm{Sm} & 51 & 60 & 25.05 & 36.15 & 42.45 \\ \text { k Sm } & 20.4 & 24 & 50.1 & 72.3 & 84.9 \\ 1.5 \mathrm{k} \mathrm{Sm} & 30.6 & 36 & 30.04 & 28.92 & 33.96 \\ 1.5 & & & 43.38 & 50.94\end{array}$

$k=1.2$ 
The local primary membrane plus bending stress intensities $\left(\mathrm{P}_{\mathrm{L}}+\mathrm{P}_{\mathrm{B}}\right)$ for normal operating conditions are

$\sigma_{h}=\frac{P R}{t}<1.5 \mathrm{Sm}$

$\sigma_{1}=\frac{P R}{2 t}+\frac{M_{d 1}+M_{d r a g}}{Z}<1.5 \mathrm{Sm}$

For accident conditions the local primary membrane plus bending stress intensities $\left(P_{L}+P_{B}\right)$ are

$\sigma_{\text {h scismic }}=\sigma_{\mathrm{h} \mathrm{SSWH}}=\frac{\mathrm{P}_{300 \mathrm{R}}}{\mathrm{t}}<1.5 \mathrm{kSm}$

$\sigma_{\text {h TSWH }}=\frac{P_{450} R}{t}<1.5 \mathrm{k} \mathrm{Sm}$

$\sigma_{1 \text { seismic }}=\frac{P_{300} R}{2 t}+\frac{M_{d l}+M_{d r a g}+M_{\text {seismic }}}{Z}<1.5 \mathrm{k} \mathrm{Sm}$

$\sigma_{1 \text { SSWH }}=\frac{P_{300} R}{2 t}+\frac{M_{d l}+M_{\text {water hammer }}}{Z}<1.5 \mathrm{k} \mathrm{Sm}$

o) TSWH $=\frac{P_{450} R}{2 t}+\frac{M_{d l}+M_{d r a g}}{Z}<1.5 k$ Sm

The local primary membrane plus bending plus secondary stress intensities $\left(P_{L}+P_{B}+Q\right)$ for normal operating conditions are

$\sigma_{h}=\frac{P R}{t}+0.5 \Delta \mathrm{T} \frac{\alpha E}{1-v}<3 \mathrm{Sm}$

$\sigma_{l}=\frac{P R}{2 t}+\frac{M_{d l}+M_{d r a g}}{Z}+\frac{6}{t^{2}} \frac{P R^{2}}{E t} 2 \beta^{2} D+0.5 \Delta T \frac{\alpha E}{1-v}<3 \mathrm{Sm}$

The compressive thermal force caused by the longitudinal differential expansion of the heat exchanger tubes and shell is conservatively neglected from ol. ASME Section VII does not consider secondary stresses during an accident condition.

The stresses are calculated in Table 6 with various wall thicknesses for normal operation, seismic and shell side water hammer accident conditions. The non-mechanistic water hammer accident condition on the tube side is discused later. Allowable stresses were previously given in Table 5. The limiting case is hoop stress during normal operation which yields a minimum tube thickness of 0.0037 " for $316 \mathrm{~L}$ stainless steel. The primary membrane, bending and secondary stresses $(\mathrm{Pl}+\mathrm{Pb}+\mathrm{Q})$ for normal operation are also close to the allowable stress. Thus, a reduction of the internal pressure from 300 psig would not change the minimum wall thickness significantly. 


\section{Table 6 Calculated ASME Section VIII Stresies} for Various Tube Wall Thicknesses

\begin{tabular}{|c|c|c|c|c|c|}
\hline \multicolumn{6}{|c|}{ Gection Properties } \\
\hline $\mathrm{t}$ (in) & 0.0490 & 0.0375 & 0.0250 & 0.0125 & 0.003 \\
\hline$R$ (in) & 0.2255 & 0.2 & & & \\
\hline$Z\left(\mathrm{in}^{3}\right)$ & .007144 & .005280 & .003 & .001 & 472 \\
\hline$\Delta R$ (in) & .000 & .0000 & .000020 & .000 & .000122 \\
\hline$\beta$ (in & 11. & & 17.10 & 24 & 46.78 \\
\hline $\mathrm{D}$ (i) & 295.2 & 132.3 & 39.20 .56 & 4.9007 & 0.12586 \\
\hline
\end{tabular}

$\begin{array}{ccccccl}\text { Normal } & \text { Operation Hoop Stresses (psi) } & & & \\ \mathbf{P m} & 1,381 & 1,758 & 2,562 & 4,974 & 16,500 & <\mathrm{Sm} \\ \mathrm{PI}+\mathrm{Pb} & 1,381 & 1,758 & 2,562 & 4,974 & 16,500 & <1.5 \mathrm{Sm} \\ \mathrm{PI}+\mathrm{Pb}+\mathrm{Q} & 6,606 & 6,984 & 7,788 & 10,200 & 21,726 & <3 \mathrm{Sm}\end{array}$

Normal Operation Longitudinal Stresses (psi)

\begin{tabular}{|c|c|c|c|c|c|c|}
\hline & & & & & & \\
\hline & 1,142 & 1,491 & 2,233 & 4,458 & 15 & \\
\hline & 1,142 & 1,491 & 2,233 & 4,4 & & $<$ \\
\hline$+Q$ & 8,629 & 9,657 & 11,853 & 18,450 & 50,002 & $<3$ \\
\hline
\end{tabular}

$\begin{array}{ccccccc}\text { Accident } & \text { Condition } & \text { Longitudinal } & \text { Stresses } & \text { - Seismic } & \text { (psi) } & \\ \mathbf{P m} & 1,235 & 1,616 & 2,427 & 4,861 & 16,484 & <\mathrm{k} \mathrm{Sm} \\ \mathrm{Pl}+\mathrm{Pb} & 1,235 & 1,616 & 2,427 & 4,861 & 16,484 & <1.5 \mathrm{k} \mathrm{Sm}\end{array}$

$\begin{array}{ccccccc}\text { Accident } & \text { Condition } & \text { Longitudinal } & \text { Stresses } & \text { - Shell } & \text { Side Water } & \text { Hammer (psi) } \\ \mathbf{P m} & 1,156 & 1,510 & 2,262 & 4,519 & 15,298 & <\mathrm{k} \mathrm{Sm} \\ \mathbf{P I}+\mathbf{P b} & 1,156 & 1,510 & 2,262 & 4,519 & 15,298 & <1.5 \mathrm{k} \mathrm{Sm}\end{array}$

Notes: $k=1.2$

Allowable stresses are given in Table 5.

Note that the stresses were developed for a 24.9" span whereas the heat exchangers with $316 \mathrm{~L}$ stainless steel have a 16.6" span. Additionally, general wall thinning was considered, whereas local wall thinning may have smaller required thickness. This analysis, with the largest span, minimum material properties and general wall thinning is bounding. A separate location dependant analysis, that relaxes these conservatisms, may be performed on a case-by-case basis to disposition indications less than $0.0037^{\prime \prime}$ thick.

The minimum allowable wall thickness for a heat exchanger tube to resist a 450 psig no. $\mathrm{n}$ mechanistic water hammer loading is $0.0046 "$ as shown in Table 7. The allowable nunmechanistic water hammer pressure that the $0.0037^{\prime \prime}$ thick tube can resist is 365 psig. Comparing these iwo results, water hammer transients require approximately 0.001 " of thickness for every 100 psig above the 300 psig design pressure. The maximum allowable internal pressure on a $0.5^{\prime \prime}$ diameter, $0.049^{\prime \prime}$ thick tube is 3600 psig during normal operation and 4300 psig during a water hammer transient, also shown in Table 7. 


\section{Table 7 Calculated ASME Section VIII Stresses for Various Pressures}

\begin{tabular}{ccccc}
$\begin{array}{c}\text { Loading } \\
\text { Condition }\end{array}$ & $\begin{array}{c}\text { Non- } \\
\text { Mechanistic } \\
\text { Water } \\
\text { Hammer }\end{array}$ & $\begin{array}{c}\text { Non- } \\
\text { Mechanistic } \\
\text { Water } \\
\text { Hammer }\end{array}$ & $\begin{array}{c}\text { Normal } \\
\text { Operation }\end{array}$ & $\begin{array}{c}\text { Non- } \\
\text { Mechanistic } \\
\text { Water } \\
\text { Hammer }\end{array}$ \\
\cline { 2 - 5 } $\begin{array}{c}\text { Internal } \\
\text { Pressure } \\
\text { (psig) } \\
\text { k }\end{array}$ & 450 & 365 & 3600 & 4300 \\
& 1.2 & 1.2 & 1 & 1.2
\end{tabular}

Section Properties

\begin{tabular}{|c|c|c|c|c|}
\hline$t$ (in) & 0.004565 & 0.003688 & 0.049000 & 0.049000 \\
\hline$R$ (in) & 0.2033 & 0.2028 & 0.2255 & 0.2255 \\
\hline $\mathrm{Z}\left(\mathrm{in}^{3}\right)$ & .000586 & .000472 & .0071.44 & .007144 \\
\hline$\Delta R($ in $)$ & . 000149 & .000122 & .000136 & .000163 \\
\hline$\beta\left(\mathrm{in}^{-1}\right)$ & 41.96 & 46.79 & 11.61 & 11.61 \\
\hline D (in Ib) & 0.238652 & $0.1258 c$ & 295.2 & 295.2 \\
\hline
\end{tabular}

Hoop Stresses (psi)

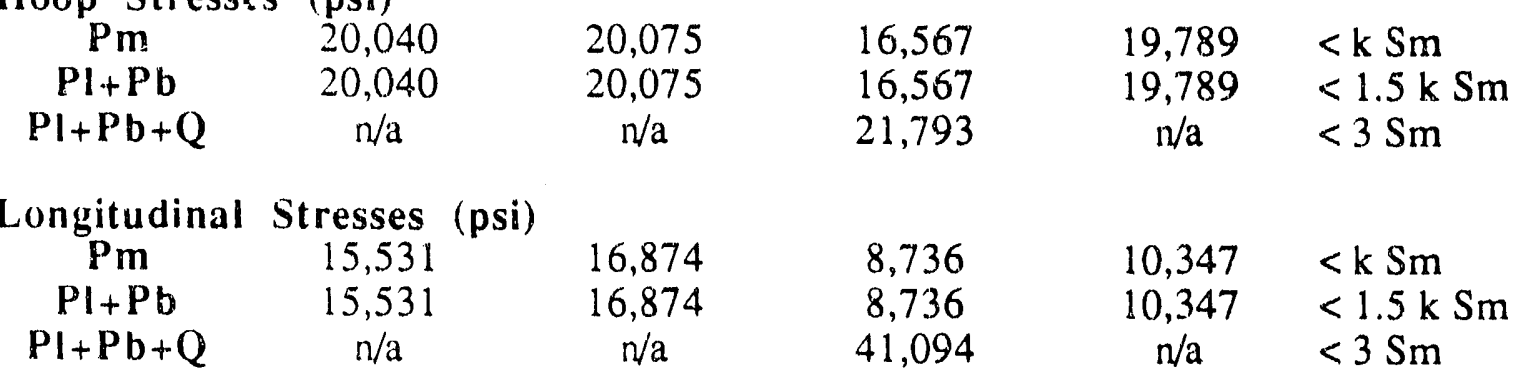

Allowable stresses are given in Table 5.

\subsection{Minimum Wall Requirements for Localized Thinning}

ASME Code Case N-480 contains an evaluation procedure and acceptance criteria for local wall thinning of piping due to erosion corrosion. The $\mathrm{N}-480$ evaluation procedures are adopted, in this analysis, for local wall thinning regardless of the wasting mechanism (erosion corrosion or wear).

If $L m(t)$ is less than or equal to $\sqrt{R t_{\min }}$, then the allowable local thickness, $t_{a}$ loc is given by curve $l$ of Figure 3 . Where $R$ is the tube outside radius and $t_{\min }$, is the minimum thickness developed in the previous section and $\mathrm{Lm}(\mathrm{t})$ is the length of the region less than $i_{\min }$ in the transverse (hoop) direction, Figure 4.

If $L m(t)$ is greater than $\sqrt{R t_{\min }}$ and $L m$ (Figure 4) is less than or equal to $2.65 \sqrt{R t_{m i n}}$, then the allowable local thickness, $t_{a l o c}$ is given by the larger of

$$
\begin{aligned}
& \frac{t_{\text {aloc }}}{t_{\min }} \geq \frac{1.5 \sqrt{R t_{\text {min }}}}{L}\left[1-\frac{t_{n u m}}{t_{\text {min }}}\right]+1 \\
& \frac{t_{\text {aloc }}}{t_{\text {min }}} \geq \frac{0.353 \mathrm{Lm}}{\sqrt{R t_{\text {min }}}}
\end{aligned}
$$


Where $L$ and $L m$ are defined in Figure 4 , and $t_{n o m}$, is the nominal tube thickness, $0.049^{\prime \prime}$.

If the requirements of the previous two criteria are not met then the allowable local thickness is given by the maximum of curve 2 in Figure 3 and

$$
\frac{t_{\text {illoc }}}{t_{\min }} \geq \frac{0.5+\frac{t_{\text {nom }}}{t_{\min } \mathrm{Z} \times \mathrm{Sm}}}{1.5}
$$

Where the section modulus $\mathrm{Z}$ is based on $\mathrm{t}_{\mathrm{nom}}$, and $\mathrm{Sm}$ is multiplied by $\mathrm{k}=1.2$ for accident conditions.

The allowable local wall thinning for normal operation, seismic and water hammer are calculated using the minimum thicknesses, pressures and moments in Table 8 . An envelop of the allowable iocal wall thinning for normal operation, seismic and water hammer accident conditions, is shown in Figure 5 , and based on $L=2$ " and minimum material properties. As discussed previously, the minimum thickness for gross wall thinning is $0.0046^{\prime \prime}$ (including the non-mechanistic tube side water hammer transient). From Figure 5, the allowable thickness for a very small wear scar is 0.0011 ". "The allowable thickness $t_{a l o c}=0.0032^{\prime \prime}$ for a wear scar tinit is 0.02 " transverse by $0.085^{\prime \prime}$ axially and less than ().0046" thick.

\section{Table 8 Load Summary for Local Wall Thinning Analysis}

\begin{tabular}{|c|c|c|c|c|}
\hline \multirow[b]{2}{*}{ Normal Operation } & \multirow{2}{*}{$\frac{\begin{array}{c}\mathfrak{t}_{\min } \\
(\mathrm{inch})\end{array}}{0.003688}$} & \multirow{2}{*}{$\begin{array}{c}\begin{array}{c}\text { Pressure } \\
\text { (psig) }\end{array} \\
300\end{array}$} & \multicolumn{2}{|c|}{$\begin{array}{l}\text { Moment } \\
\text { (in-lbs) }\end{array}$} \\
\hline & & & 3.23 & $\mathrm{M}_{\mathrm{dl}}+\mathrm{M}_{\mathrm{drag}}$ \\
\hline Cold End Normal Operation & 0.002180 & 110 & 3.23 & $\mathrm{M}_{\mathrm{dl}}+\mathrm{M}_{\mathrm{drag}}$ \\
\hline Accident & & & & \\
\hline Seismic & 0.003038 & 300 & 3.89 & $\mathrm{M}_{\mathrm{dl}}+\mathrm{M}_{\mathrm{drag}}+\mathrm{M}_{\text {seismic }}$ \\
\hline Shell Side Water Hammer & 0.003037 & 300 & 3.33 & $\mathrm{M}_{\mathrm{dl} l}+\mathrm{M}_{\text {water hammer }}$ \\
\hline Tube Side Water Hammer ${ }^{1}$ & 0.004565 & 450 & 3.23 & $\mathrm{M}_{\mathrm{dl}}+\mathrm{M}_{\mathrm{drag}}$ \\
\hline
\end{tabular}

The allowable wear scar for normal operation of a tube at the cold end of the heat exchanger, with a differential pressure of 110 psig is shown in Figure 6 . At this operating condition, without accident loadings, the minimum thickness for gross wall thinning is (0.)(0)218". The allowable thickness for a very small wear scar is $0.000654 "$. The allowable thickness $\mathrm{t}_{\text {aloc }}=0.00 \mathrm{i} 7$ " for a wear scar that is 0.02 " transverse by $0.085^{\prime \prime}$ axially and less than $0.00218^{\prime \prime}$ thick.

1 This is a non-mechanistic loading. 


\subsection{Allowable Flaw Sizes}

Instability and allowable flaw sizes are calculated with the limit load criteria based in ASME Section XI, Appendix C-3320 and C-3420. For circumferential flaws,

$S F \times P b \geq \frac{6 S m}{\pi}\left(2 \sin \beta-\frac{a}{t} \sin \theta\right)$

where $\beta=\frac{1}{2}\left(\pi-\frac{\mathrm{a}}{\mathrm{t}} \theta-\pi \frac{\mathrm{SF} \mathrm{Pm}}{3 \mathrm{Sm}}\right)$

$\theta, a, t, R$ and $\beta$ are shown in Figure 7 , $\mathrm{a} \leq 0.75 \mathrm{t}$,

$\mathrm{SF}$ is the factor of safety,

$\mathrm{Pm}$ is the membrane stress, $\mathrm{Pm}=\frac{\mathrm{PR}}{2 \mathrm{t}}$,

$\mathrm{Pb}$ is the bending stress, $\mathrm{Pb}=\frac{\mathrm{M}}{\mathrm{Z}}$ and $\mathrm{Z}$ is the section modulus.

When $(\beta+\theta)>\pi$,

$\mathrm{SF} \times \mathrm{Pb} \geq \frac{6 \mathrm{Sm}}{\pi}\left(2-\frac{\mathrm{a}}{\mathrm{t}}\right) \sin \beta$

where $\beta=\frac{\pi}{2-\frac{a}{t}}\left(1-\frac{a}{t}-\frac{S F P m}{3 S m}\right)$

$a \leq 0.75 t$

For axial fl vs,

$\sigma h=\frac{P \times R}{t} \leq \frac{3 S m}{S F}\left[\frac{\frac{t}{a}-1}{\frac{t}{a}-\frac{1}{M_{2}}}\right]$

where $M_{2}=\sqrt{1+\frac{1.61 \text { length }}{4 R^{2}}}$

$a \leq 0.75 t$

the length is limited to $l_{c r i t}$ where $L_{c r i t}$ is defined by

$$
\begin{aligned}
& \sigma h=\frac{3 \mathrm{Sm}}{\mathrm{M}_{2}} \text {, Solving } \mathrm{M}_{2} \text { for the length yields } \\
& \text { length } \leq L_{\text {crit }}=\sqrt{\left[\left(\frac{3 \mathrm{Sm}}{\sigma \mathrm{h}}\right)^{2}-1\right] \frac{4 \mathrm{R} t}{1.61}}
\end{aligned}
$$

if length $>1_{\text {crit }}$, ASME Section XI, IWB-3514-3, shall be used. 
Allowable flaw sizes have a factor of safety of 3 on normal operating loads and a factor of safety of 1.5 on emergency or faulted conditions, which is consistent with Regulatory Guide 1.191. The flow stress of $3 \mathrm{Sm}$ is used where $\mathrm{Sm}$ is the minimum design stress intensity given in Table 5 , or $16.7 \mathrm{ksi}$.

Normal operating loadings consist of 300 psig internal pressure combined with $\mathrm{M}_{\mathrm{dl}}$ and $\mathrm{M}_{\mathrm{drag}}$ as shown in Table 8. Seismic accident conditions consist of the normal operating loadings combined with seismic loading. The water hammer accident condition, on the shell side, consist of 300 psig internal pressure combined with $\mathrm{M}_{\mathrm{dl}}$ and $\mathrm{M}_{\text {water hammer. }} \mathrm{A}$ non-mechanistic water hammer accident is postulated on the tube side with 450 psig internal pressure combined with $\mathrm{M}_{\mathrm{dl}}$ and $\mathrm{M}_{\mathrm{drag}}$. Secondary stresses due to (1) the radial restraint of the tubing; and (2) the $\Delta \mathrm{T}$ through the thickness of the tube; are not included in the limit load flaw stability analysis. These secondary loads are relieved during the formation of the plastic hinge.

The allowable flaw sizes ${ }^{1}$ for normal operating and the controlling accident loadings are given in Figures 8 and 9 for $0.049^{\prime \prime}$ and $0.025^{\prime \prime}$ tube wall thicknesses. Note that the flaw sizes given in Figures 8 and 9 do not contain allowances for further wall thinning or crack growth.

Normal operation controls the allowable flaw size for both cases, regardless of orientation or thickness. The allowable length of a long, part through wall axial flaws, $l_{\text {crit, }}$ is limited by the assumed non-mechanistic water hammer pressure of 450 psig. Relaxing this artificial pressure, the allowable length is limited by normal operation. A summary of the allowable flaw sizes is given in Table 9.

\section{Table 9 Summary of Allowable Flaw Sizes}

Tube Wall Thickness

$0.049 \quad 0.025$

\section{Circumferential Flaws}

Throughwall

Part Throughwall

\section{Axial Flaws}

Throughwall

Part Throughwail
$65 \%$ Circumference

94\% Depth

2 inches

$91 \%$ Depth $\times 6$ "long
$56 \%$ Circumference

$89 \%$ Depth

0.74 inches

$85 \%$ Depth $\times 2.2$ " long

Notes: \% Depth $=\frac{\text { Crack Depth }}{\text { Tube Wall Thickness }} \times 100$

$\%$ Circumference $=\frac{\text { Crack Length }}{\text { Tube Circumference }} \times 100$

1 Neglecting the $a \leq 0.75 \mathrm{t}$ limitation on the limit load equations. 
The allowable size of a circumferential flaw is not sensitive to variations in wall thicknesses between $0.049^{\prime \prime}$ and $0.025^{\prime \prime}$. Whereas reducing the wall thickness by one-half reduces the allowable flaw length of a throughwall axial flaw by more than one-half. Similarly, reducing the wall thickness by one-half reduces the maximum length of a part throughwall flaw, Lcrit, by more than one-half. Lcrit for a part throughwall axial crack in $0.0375^{\prime \prime}$ thick tubing is 4". Thus, linear interpolation for wall thicknesses between $0.049^{\prime \prime}$ and $0.025^{\prime \prime}$ is permissible. 


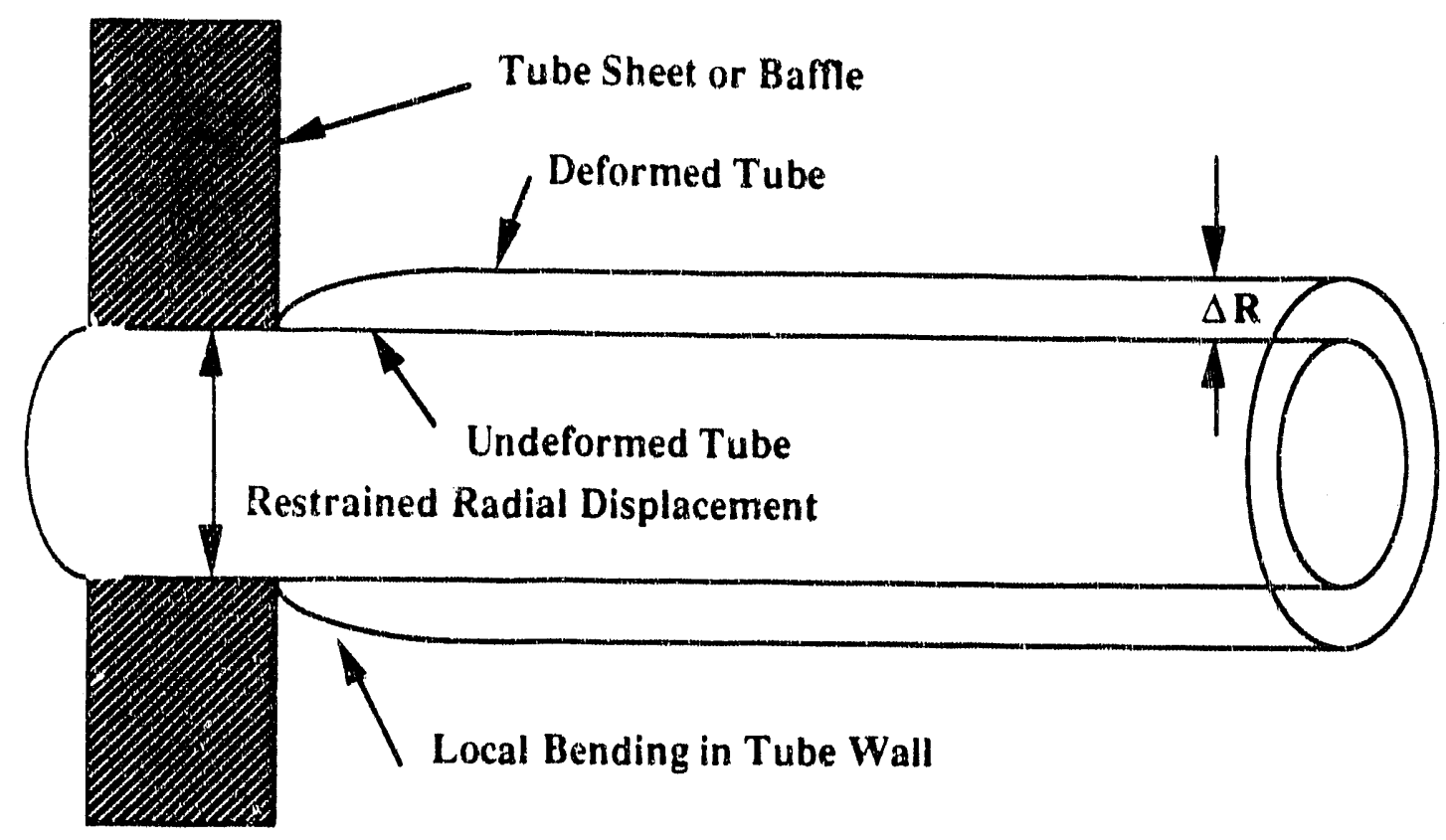

Figure 2 Tubing Restrain at Tube Sheet or Baffle

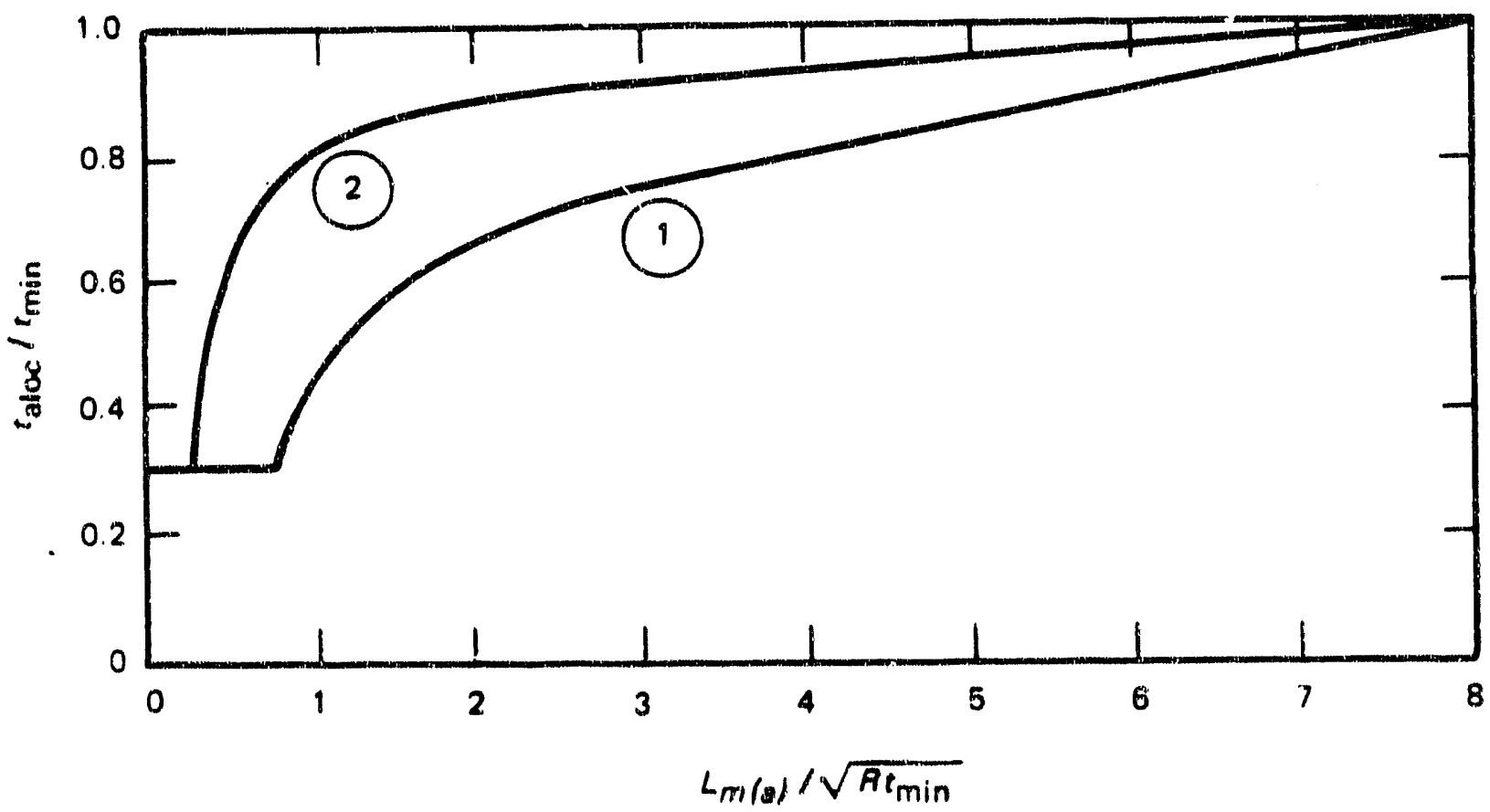

Figure 3 Allowable Depth and Length of Locally Thinned Areas [22] 


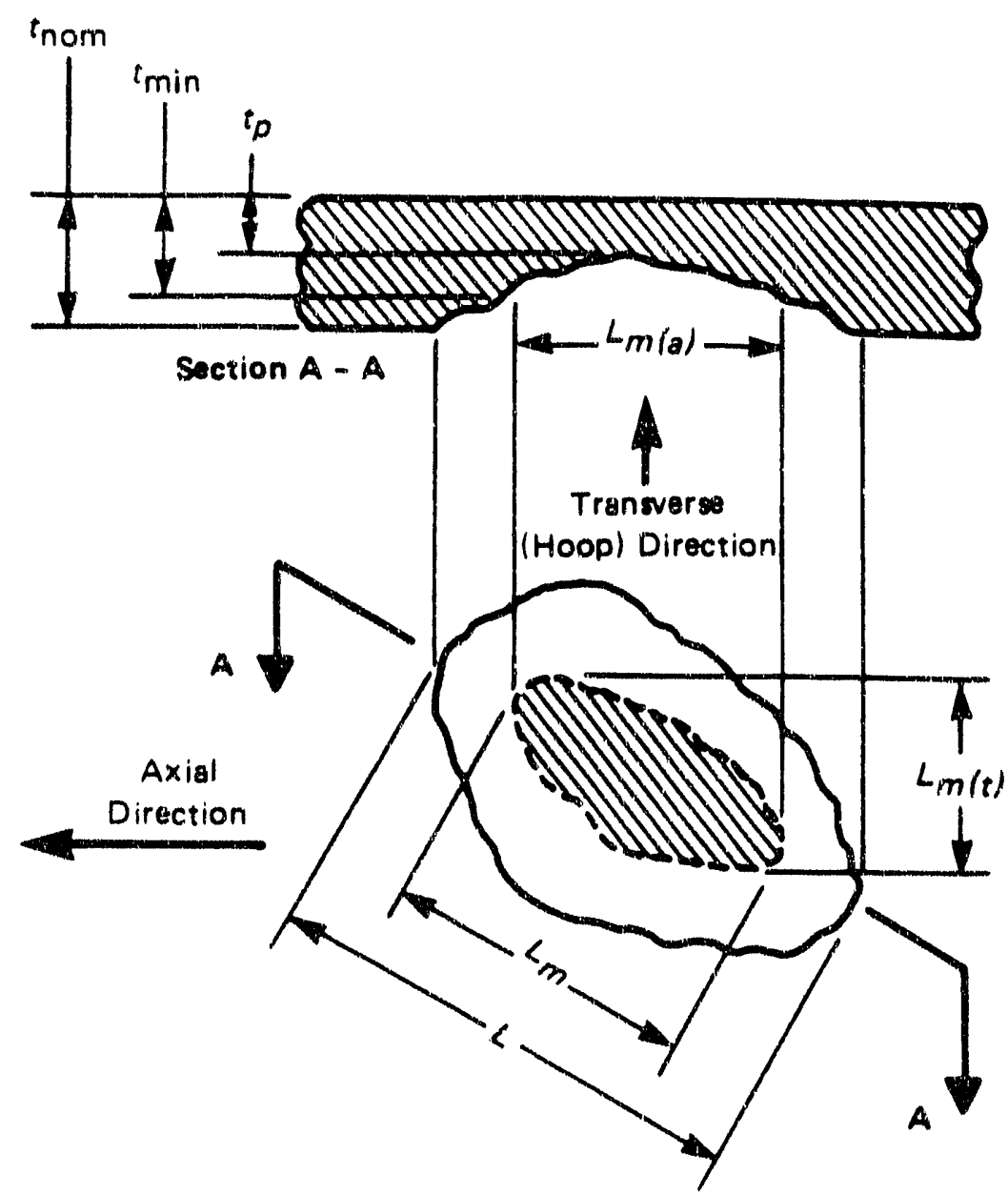

Figure 4 Illustration of Local Wall Thinning [22] 


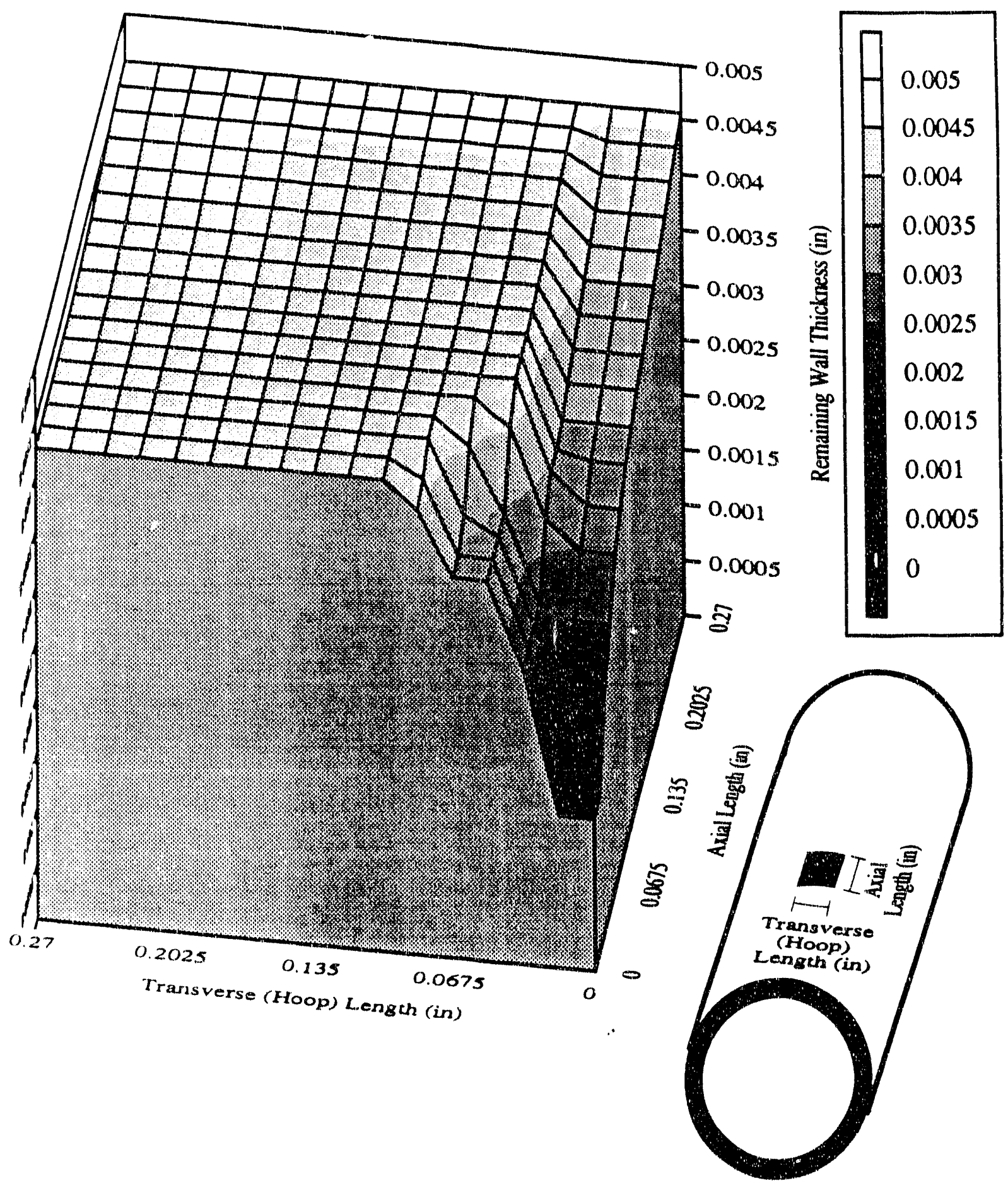

Figure 5 Allowable Locally Thinned Areas for Normal Operating and Accident Conditions 


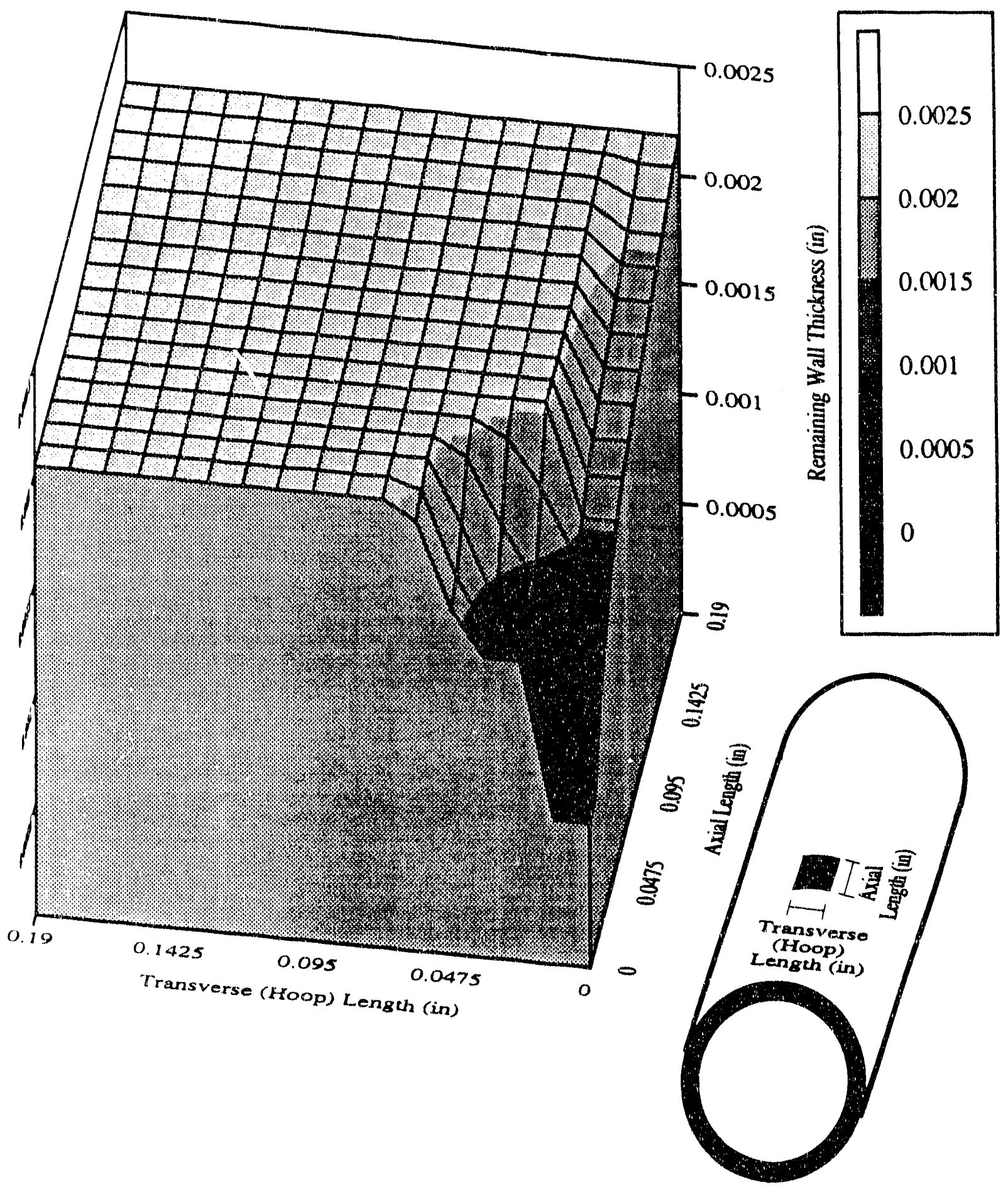

Figure 6 Allowable Locally Thinned Areas for Normal Operating Conditions on the Cold End of the Heat Exchanger ( $\triangle P=110$ psid) 


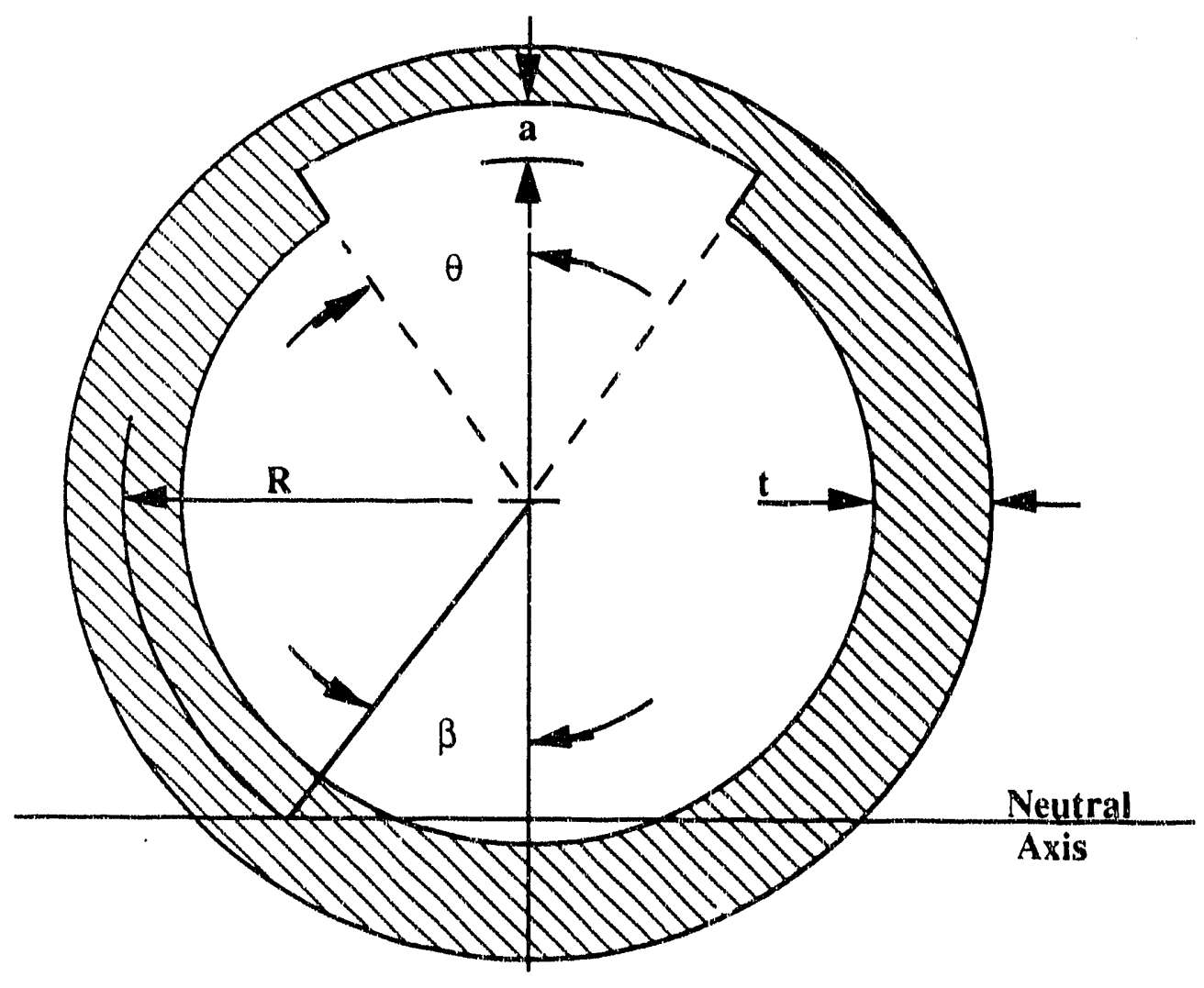

Figure 7 Cross Section of Flawed Pipe 


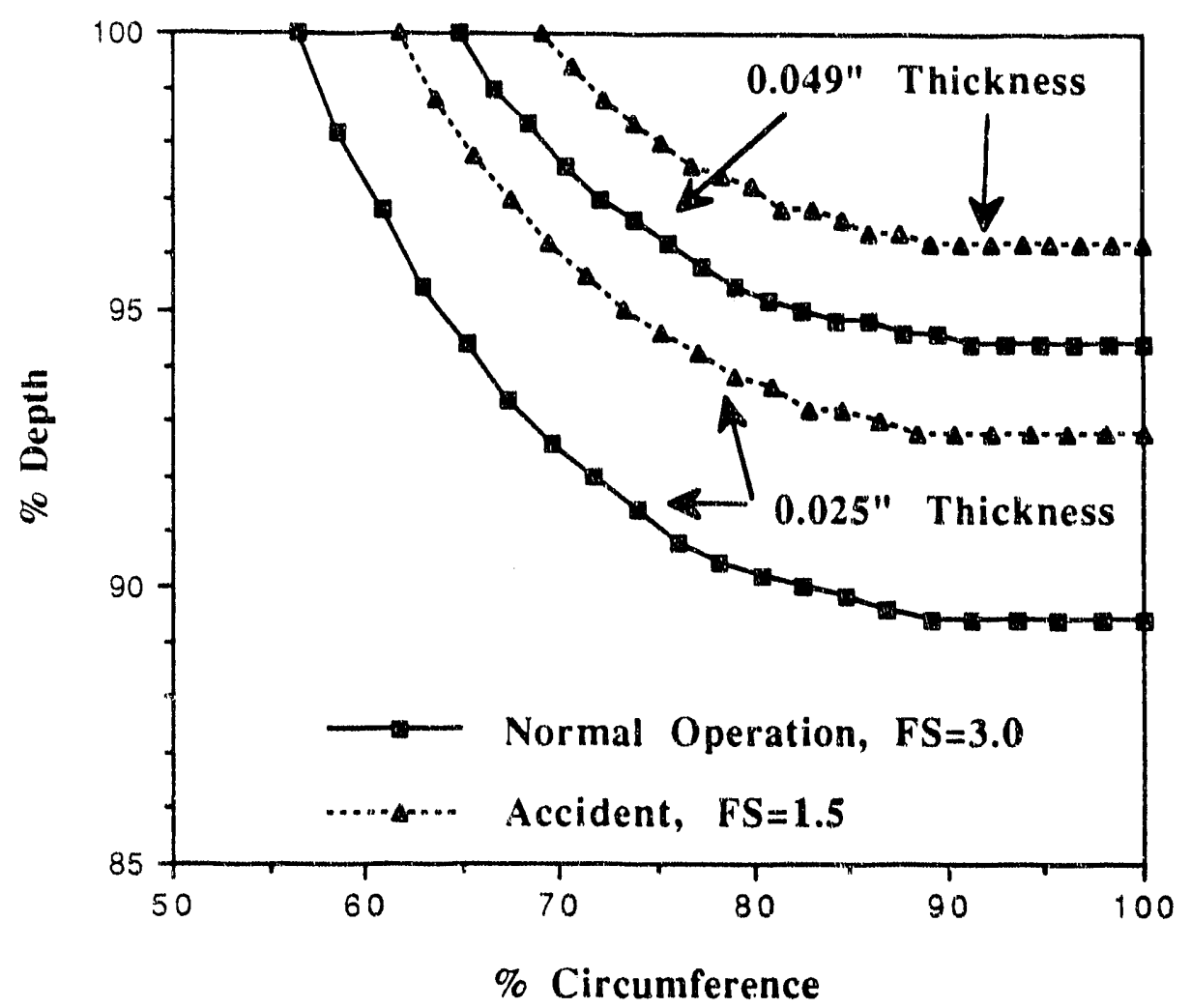

Figure 8. Allowable End of Life Flaw Size for Circumferential Flaws (not including allowances for crack growth and wall thinning)

Notes:

$\%$ Depth $=\frac{\text { Crack Depth }}{\text { Tube Wall Thickness }} \times 100$

. $\quad \%$ Circurnference $=\frac{\text { Crack Length }}{\text { Tube Circumference }} \times 100$ 


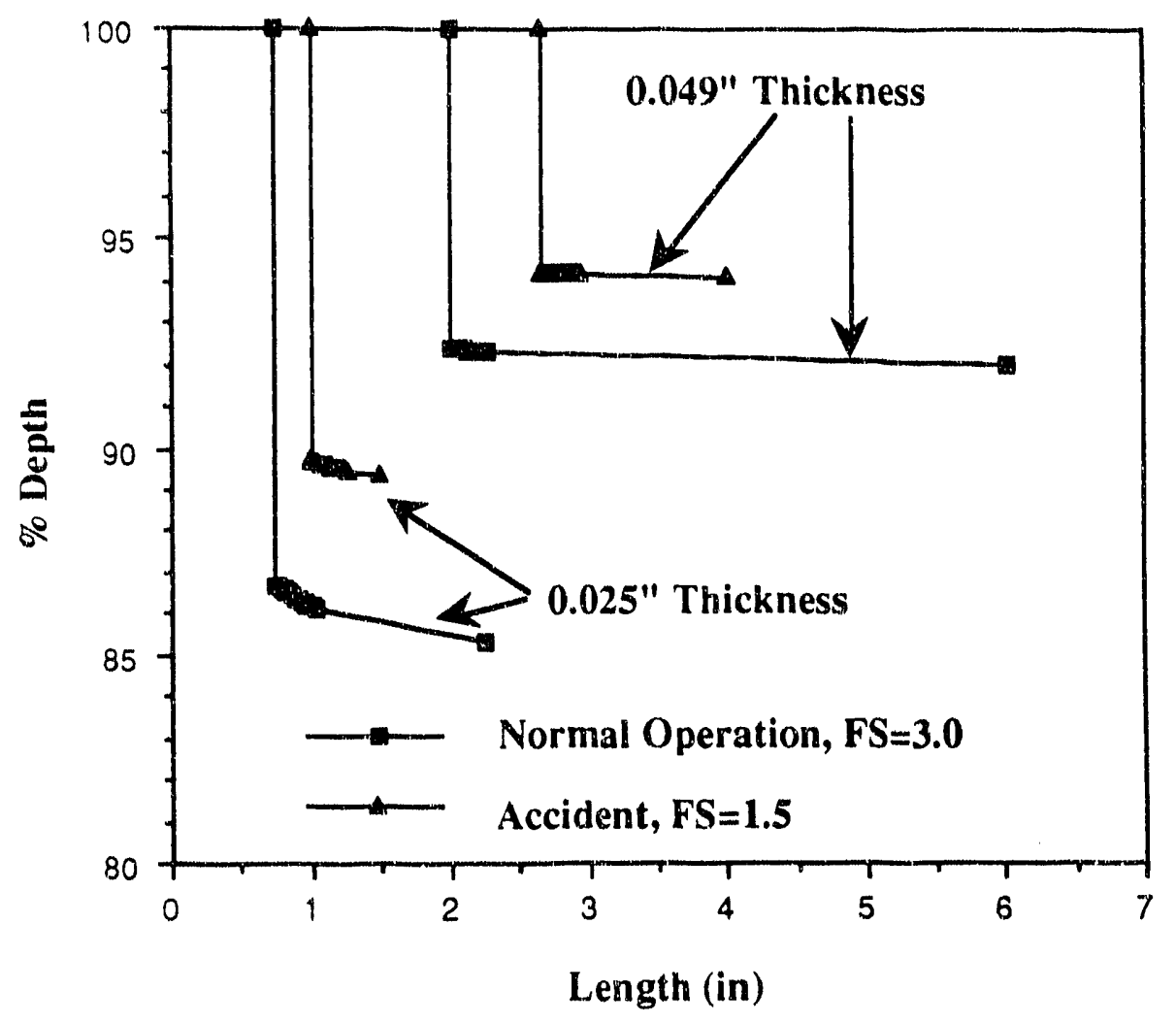

Figure 9 Allowable End of Life Flaw Size for Axial Flaws (not including allowances for crack growth and wall thinning)

Notes:

$$
\% \text { Depth }=\frac{\text { Crack Depth }}{\text { Tube Wall Thickness }} \times 100
$$




\section{OPERABILITY REQUIREMENTS}

An operational criteria for heat exchanger tube service is leakage. Historically, heat exchangers have been removed from service if total leakage from the heat exchanger increased from no leakage up to typically less than $1 \mathrm{lb}$./day. The present guideline for scheduled replacement of an individual heat exchanger due to leakage is $0.5 \mathrm{lbs}$./day [9]. This leakage level is monitored by the gamma monitors and grab sample analysis.

The IGSCC Leak Rate Model [10] is used to calculate the tube leakage with various assumed throughwall crack sizes. The IGSCC leak rate model was developed for leakage through intergranular stress corrosion cracks. This model has been benchmarked against Battelle Columbus experimental data with flows between 200 and 38,000 lbs./day. The IGSCC leak rate model's friction factor is greater than 100 for flows less than $1 \mathrm{lbs}$./day. This is judged to be conservative, even for highly branched transgranular cracks.

The crack opening calculation is based on linear elastic fracture mechanics with a correction for small scale yielding, using primary tubing stresses [16]. The change in crack opening area due to thermal stresses was neglected in this analysis.

The flow through an orifice is used to calculate the leakage through a pit

$Q=C_{d} P \frac{\pi D^{2}}{4} \sqrt{\frac{2 g \Delta p}{\rho}}(2078.5)$

Where $Q$ is the flow in lbs/day

$\mathrm{D}$ is the diameter of the pit (in)

$\mathrm{Cd}$ is the orifice coefficient $\approx 0.82$

$\mathrm{p}$ is the density $\left(\mathrm{lb} . / \mathrm{ft}^{3}\right)$

$\mathrm{g}=386.4 \mathrm{in} / \mathrm{sec}^{2}$

$\Delta p$ is the pressure drop (psi)

At the hot end of the heat exchanger, the differential pressure between the tube and shell side fluids is 180 psi, Table 1 , while at the cold end of the heat exchanger, the differential pressure is 110 psi.

Total heat exchanger leakage may be conservatively ascribed to a single tube in applying the results of the Leak Rate Model to calculate leakage flaw sizes. The leakage flaw sizes are compared to the flaw allowable lengths to provide a margin of safety on the leakage flaw size.

The results of the Leak Rate Model calculations for circumferential and axial tube cracks for tubes near the heat exchanger inlet and outlet (hot and cold ends) are shown in Figures 10 and 11. Similarly, the leak rate through a pit is shown in Figure 12. The flow rates (lbs./day) versus crack length are shown for $0.049^{\prime \prime}$ and $0.025^{\prime \prime}$ heat exchanger tube thicknesses. For the $0.049^{\prime \prime}$ thick tubing, the crack lengths required to obtain $0.5 \mathrm{lbs}$./day leakage (reference leakage size crack) range from approximately 0.4 " on the hot end and $0.6^{\prime \prime}$ on the cold end. In the previous chapter, the allowable throughwall flaw length was determined to be 1 " (65\% of the circumference) for a circumferential flaw and 2 " for an axial flaw with factors of safety (applied to stress) of 3 on normal operation and 1.5 on accident conditions. The allowable flaw lengths are recalculated with a uniform factor of safety of 3 on both normal operation and accident conditions in Table 10. Since the 
allowable flaw size is larger than the leakage flaw size, the tubing has a structural margins on stress which are greater than 3 .

The structural margin on crack size is the ratio of the crack instability length to the $0.5 \mathrm{lb}$./day leak size crack (reference leakage size crack). The crack instability length is calculated with the limit load and a factor of safety (on stress) of one. The instability length, reference leakage size crack and structural margin on length are given in Table 10. As seen in Table 10, the minimum structural margin on length is 1.9 , which is adequate. As the thickness decreases, the limiting structural margin increases because the reference leakage size crack decreases more than the instability length.

The structural integrity of deep pits is bounded by a throughwall crack. Pit sizes approaching the allowable throughwall crack size, Table 9 , are not credible. Thus, the remaining ligament at the head of the pit is conservatively limited to the minimum wall thickness.

SRS heat exchanger tube structural requirements developed in the previous chapter define minimum thicknesses and allowable flaw lengths to avoid gross rupture of the tube. The structural margins on stress and crack length, Table 10, demonstrate that a degraded tube with a throughwall crack would leak enough moderator to allow detection, and without the possibility of failure by gross rupture. Furthermore, the Site Safety Analysis Report (SAR) explicitly considers a bounding scenario of full tube rupture.

\section{Table 10 Structural Margins on length for Heat Exchanger Tubing}

\begin{tabular}{lccccc}
$\begin{array}{l}\text { Flaw } \\
\text { Orientation }\end{array}$ & $\begin{array}{c}\text { Reference } \\
\text { Leakage } \\
\text { Size Crack } \\
\text { (in) }\end{array}$ & $\begin{array}{c}\text { Allowable } \\
\text { Lengthb } \\
\text { (in) }\end{array}$ & $\begin{array}{c}\text { Structural } \\
\text { Margin on } \\
\text { Stress }\end{array}$ & $\begin{array}{c}\text { Instability } \\
\text { Lengthc } \\
\text { (in) }\end{array}$ & $\begin{array}{c}\text { Structural } \\
\text { Margin on } \\
\text { Length }\end{array}$ \\
\hline
\end{tabular}

\section{$0.049^{\prime \prime}$}

\section{thickness}

Circum.

Axial

0.6

0.96

$>3$

1.13

1.9

$0.025^{\prime \prime}$

\section{thickness}

Circum.

0.6

1.3

$>3$

4.00

6.7

Axial

0.4

0.80

$>3$

1.03

2.6

Pit

0.001

0.48

very large

2.25

5.6

a) $0.5 \mathrm{lbs}$./day

b) Allowable length with a factor of safety of 3 on both normal operating and ccident conditions.

c) Allowable length with a factor of safety of 1 on both normal operating and accident conditions. 


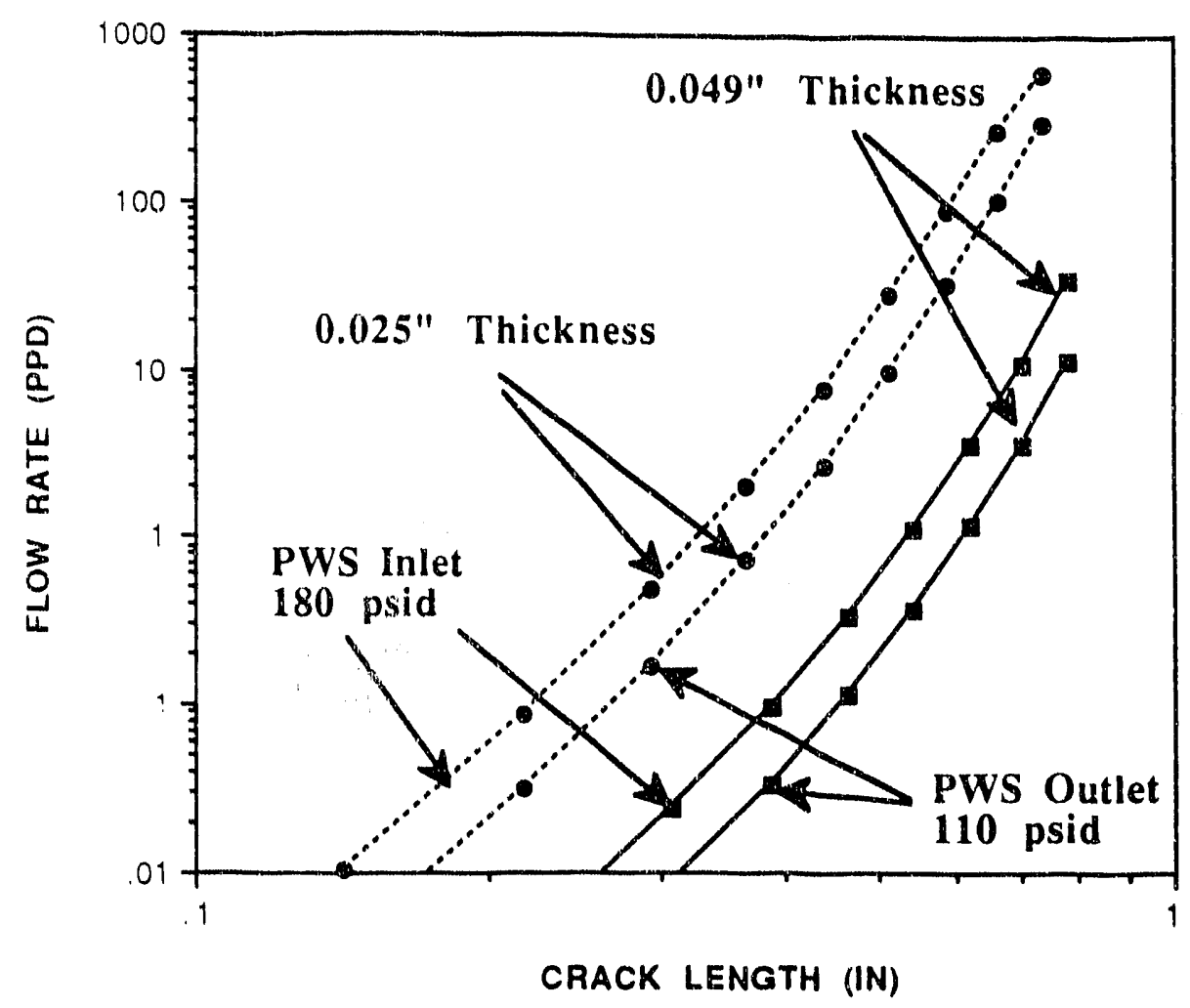

Figure 10 Leak Rate for a Circumferential Heat Exchanger Tube Crack

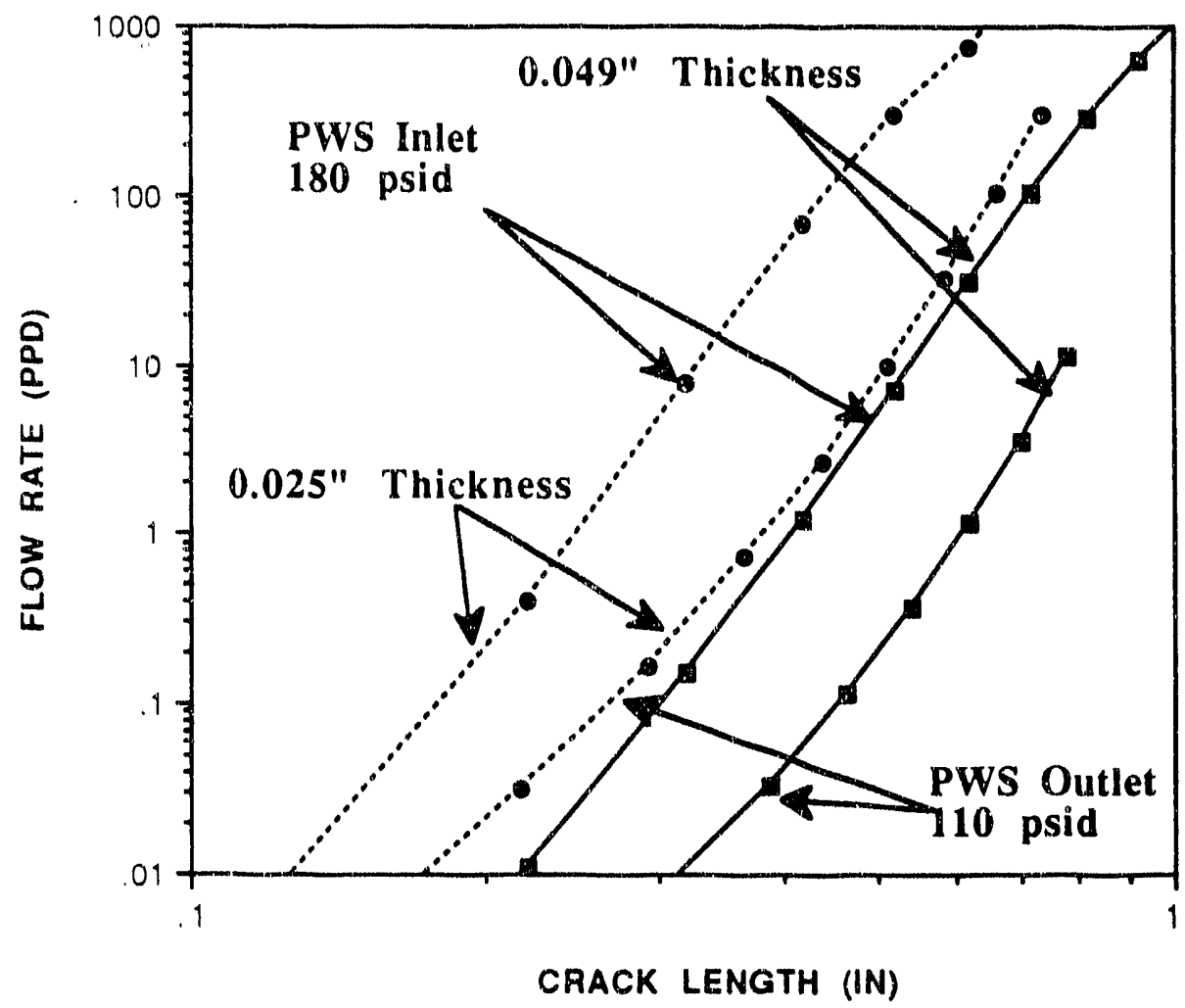

Figure 11 Leak Rate for an Axial Heat Exchanger Tube Crack 


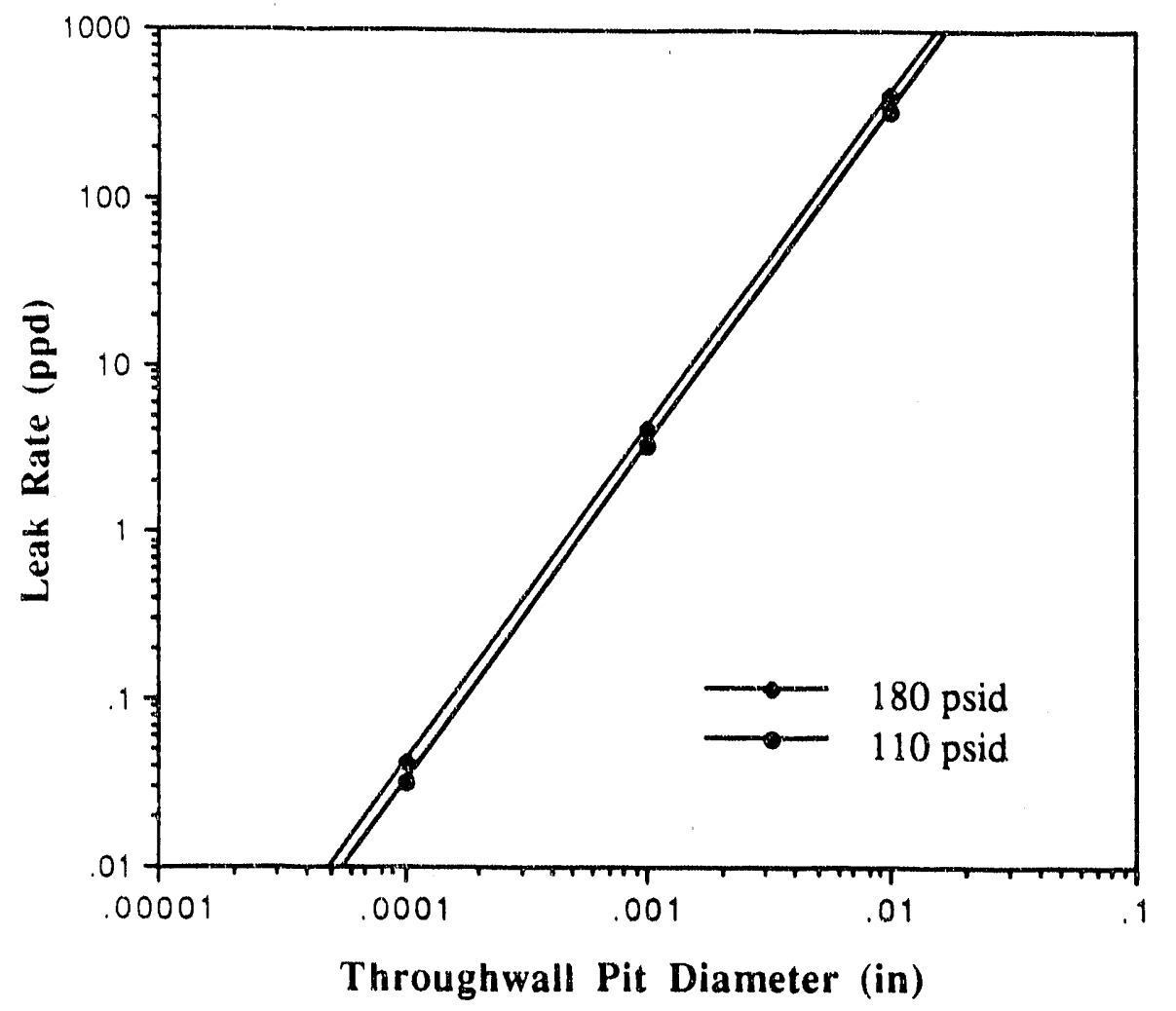

Figure 12 Leak Rate for a Heat Exchanger Tube Pit 


\section{INSPECTION ACCEPTANCE CRITERIA}

The structural and operation requiremens developed in the previous two chapters are synthesized into an ASME Section XI compatible end-of-evaluation period acceptance criteria. Allowances for further wall thinning and/or crack growth are not included in this criteria. This acceptance criteria is intended to 1) prevent gross rupture, and 2) prevent leakage, based on the configuration at the end of an evaluation period.

To prevent leakage, ASME Section XI does not allow throughwall cracks and limits the crack depth of part throughwall flaws to $75 \%$ of the thickness. Thus, this structural acceptance criteria limits flaw depths to $75 \%$ of the remaining tube wall thickness.

ASME Section XI restricts the length of part throughwall axial flaws to $I_{\text {crit. }}$ Part throughwall axial flaws longer than $L_{c r i t}$ are governed by ASME Section XI, IWB-3514-3, which does not specifically address tubing. Long, part throughwall axial flaws, less than $10 \%$ of the wall thickness deep, are judged to be consistent with the intent of ASME Section XI, and are allowed in this acceptance criteria.

The local wall thinning criteria developed in Chapter 4 is the acceptance criteria for pits and wear scars. The minimum required remaining ligament is derived from Figure 5.

Combining these limitations, with the minimum wall thickness criteria yields the heat exchanger tubing allowable end-of-evaluation period acceptance criteria, shown in Table 11. 
Table 11a Heat Exchanger Tubing Allowable End-Of-Evaluation Period Wall Thickness ${ }^{c}$

\begin{tabular}{ccccc}
$\begin{array}{c}\text { Remaining } \\
\text { Wall } \\
\text { Thickness }\end{array}$ & $\begin{array}{c}\text { General } \\
\text { Thinning }\end{array}$ & $\begin{array}{c}\text { Local } \\
\text { Thinning }\end{array}$ & $\begin{array}{c}\text { Circumferential } \\
\text { Cracks }\end{array}$ & $\begin{array}{c}\text { Axial } \\
\text { Cracks }\end{array}$ \\
\hline $0.049^{\prime \prime}$ & Permitted & Permitted & Table 11b & Table 11c \\
$0.025^{\prime \prime}$ & Permitted & Permitted & Table 11b & Table 11c \\
$0.005^{\prime \prime}$ & Permitted & Permitted & $\begin{array}{c}\text { Not permitted without } \\
\text { further evaluation }\end{array}$ & $\begin{array}{c}\text { Not permitted without } \\
\text { further evaiuation }\end{array}$ \\
$0.004^{\prime \prime}$ & Not permitted & ${\text { ODe }<1 / 16^{\prime \prime}}^{\prime \prime}$ & Not permitted & Not permitted \\
0.002 & Not permitted & ${\text { ODe }<1 / 32^{\prime \prime}}^{\prime}$ & Not permitted & Not permitted \\
0.0014 & Not permitted & ODe $<1 / 50 "$ & Not permitted & Not permitted \\
$<0.0014$ & Not permitted & Not permitted & Not permitted & Not permitted
\end{tabular}

\section{Table 11b Heat Exchanger Tubing Allowable End-Of-Evaluation Period Flaw Depth To Thickness Ratios for Circumferential Flawsb,d}

\begin{tabular}{lcccccccc} 
& \multicolumn{8}{c}{ Ratio of Flaw Length to Pipe Circumference } \\
\cline { 2 - 8 } Thickness & 0 & 0.1 & 0.2 & 0.3 & 0.4 & 0.5 & 0.75 & 1.0 \\
\hline $0.049^{\prime \prime}$ & 0.75 & 0.75 & 0.75 & 0.75 & 0.75 & 0.75 & 0.75 & 0.75 \\
$0.025^{\prime \prime}$ & 0.75 & 0.75 & 0.75 & 0.75 & 0.75 & 0.75 & 0.75 & 0.75
\end{tabular}

\section{Table 11c Heat Exchanger Tubing Allowable End-Of-Evaluation Period Flaw Depth To Thickness Ratios for Axial Flawsa,b,d}

\begin{tabular}{lcccccccc} 
& \multicolumn{8}{c}{ Flaw Length (inches) } \\
\cline { 2 - 8 } Thickness & 0 & 1 & 2 & 3 & 4 & 5 & 6 & 7 \\
\hline $0.049^{\prime \prime}$ & 0.75 & 0.75 & 0.75 & 0.75 & 0.75 & 0.75 & 0.75 & 0.10 \\
$0.043^{\prime \prime}$ & 0.75 & 0.75 & 0.75 & 0.75 & 0.75 & 0.75 & 0.10 & 0.10 \\
$0.025^{\prime \prime}$ & 0.7 .5 & 0.75 & 0.75 & 0.10 & 0.10 & 0.10 & 0.10 & 0.10
\end{tabular}
a) Interpolation between thicknesses is permitted.
b) Flaws in tubing with wall thicknesses less than 0.025 "are not permissible without further evaluation.
c) Remaining wall thicknesses less than 0.005 " are not permissible without further evaluation.
d) Allowances for crack growth and wall thinning are not included.
e) OD is the diameter of th? pit or wear scar with a thickness less than 0.005 " 


\section{REFERENCES}

1 WSRC-TR-91-42-DRAFT, Process Water Heat Exchanger Design and Operating History, D. R. Ketcham and K. E. Kehr.

2 Stainless Steel and High Alloy Tubing and Pipe, Trent Tube Division of Cruciable Materials Corp. Literature

3 NES-ETH-920039, HX Inlet Pressure with Bingham Pump Dead-Headed, J. Whitehouse, January 1992.

4 Bases for Plugging Degraded PWR Steam Ginerator Tubes, U.S. NRC Regulatory Guide 1.121, 1976.

5 Inservice Inspection of Pressurized Water Reactor Steam Generator Tubes, U.S. NRC Regulatory Guide 1.83, 1975.

6 Cal? \#M-CLC-K-00225, PW HX Tube Stress Analysis, H. Flanders, G. B. Rawls and B. J. Bryant, January 1992.

7 ASME Boiler and Pressure Vessel Code, Sections III (1989), VIII (1986) and XI (1989).

8 Formulas for Stress and Strain, R. J. Roark and W. C. Young, 1975.

9 DPSOL 105-2313, Determining D20 Leakage from Heat Exchangers.

10 WSRC-RP-90-93, Reactor Materials Program Single Phase Leak Rates Tirough Intergranular Stress Corrosion Cracks, S. A. Swamy, G. E. Mertz and K. J. Stoner., February 1990.

11 Flow-Induced Vibration, R.D. Blevins.

12 DPST-87-822, PW System Water Hammer Stress Analysis - Phase I, N. T. Hightower, 1987.

13 DPST-88-825, CW and PW System Water Hammer Stress Anclysis - Phase II, N. T. Hightower, et al, 1988.

14 DPST.89-298, Water Harnmer Analysis of the January 22, 1989 Event in Building 190-K, N. T. Hightower, W. F. Hillyard, 1989.

15 WSRC-RP-89-646, Bechtel Water Hammer Analysis of the January 22, 1989 Event in Bullding 190-K, N. T. Hightower, A. H. Arastu, 1989.

16 WSRC-RP-90-91, Reactor Materials Program Leak-Before-Break Analysis of the Reactor Process Water Piping System, R. L. Sindelar, G. E. Mertz and K. J. Stoner, March 1990.

17 RRD-RSE-910465, Rotovalve and Septifoil Valve Stroke Times, D. G. Hoezee, D. M. Barnes, W. S. Large, April 1991. 
18 SRL-MTS-921002, Materials of Construction for Heal Exchangers - 105K, D. M. Barnes and D. R. Ketchum, February 1992.

19 Introduction to Fluid Mechanics, R. W. Fox and A. T. McDonald, 1987.

20 Standard Handbook for Mechanical Engineers, T. Ba'dmeister and L. S. Marks, Editors, 1967.

21 Formulas For Stress and Strain, R. J. Roark and W. C. Young, 1975.

22 ASME Code Case N-480 Examination Requirements for Pipe Wall Thinning Due to Single Phase Erosion and Corrosion Section XI, Division 1, May 1990.

23 Fluidelastic Vibration Assessment, Westinghouse Science and Technology Center Inter-Office Memo from H. J. Connors to J. A. Begley, 2/14/92. 

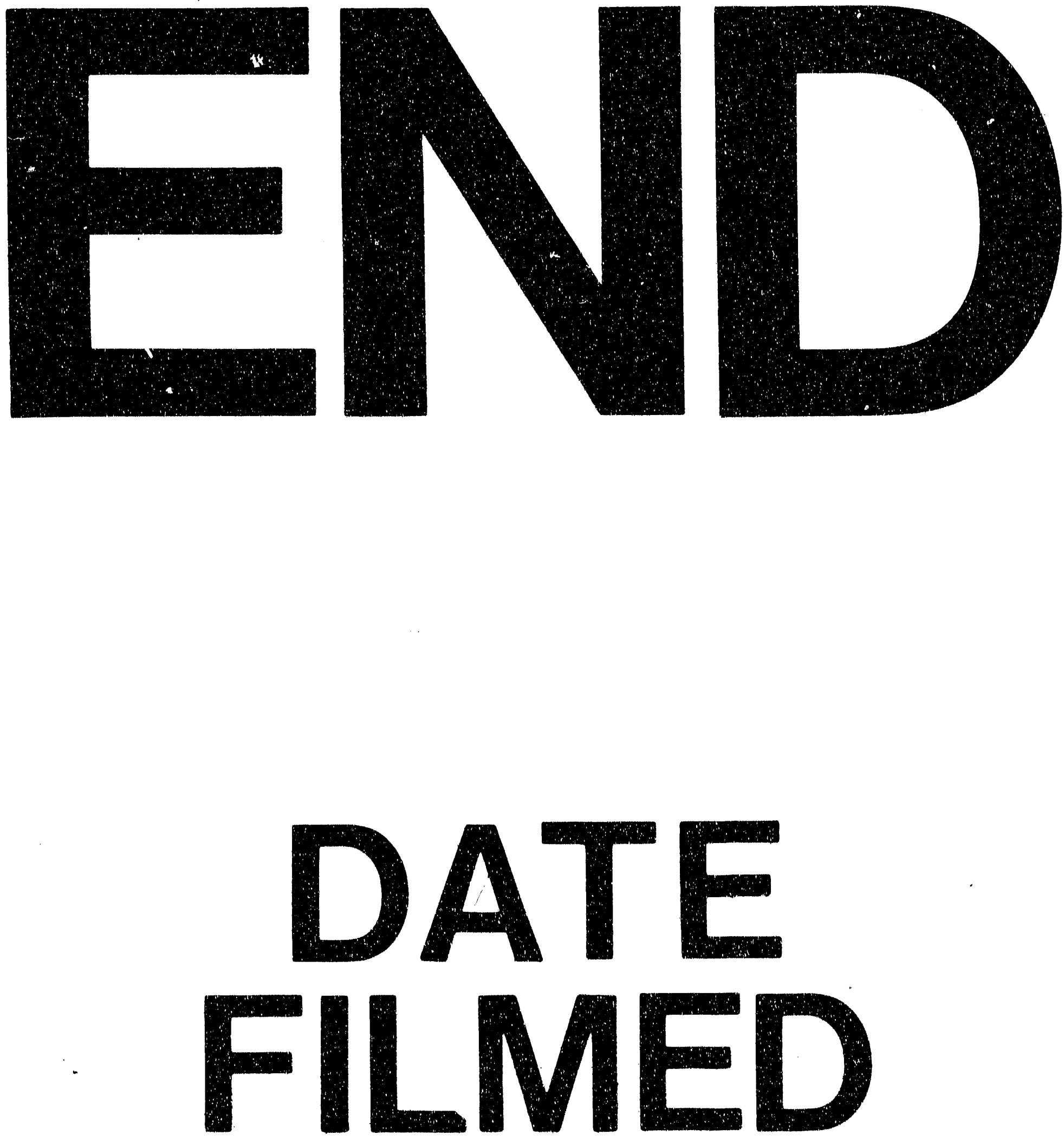

F

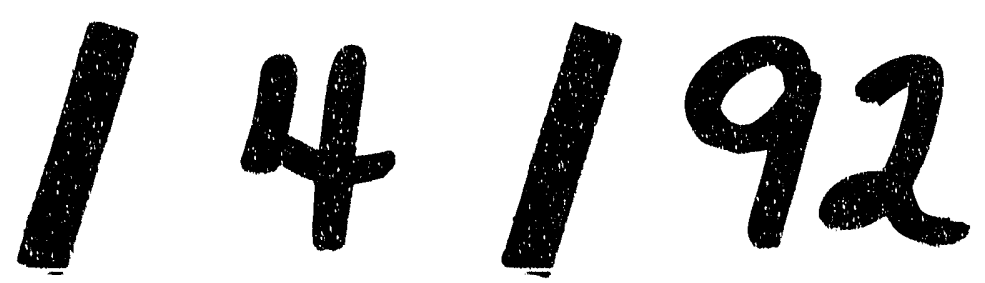


